Article

\title{
Atomic Layer Deposition of Ni-Co-O Thin-Film Electrodes for Solid-State LIBs and the Influence of Chemical Composition on Overcapacity
}

\author{
Yury Koshtyal ${ }^{1}$, Ilya Mitrofanov ${ }^{1}$ (D) Denis Nazarov ${ }^{1,2}$, Oleg Medvedev ${ }^{1}$, Artem Kim ${ }^{1}$, Ilya Ezhov ${ }^{1}$, \\ Aleksander Rumyantsev ${ }^{1,3}$, Anatoly Popovich ${ }^{1}$ and Maxim Yu. Maximov $1, * \mathbb{C}$ \\ 1 Peter the Great Saint-Petersburg Polytechnic University, 195221 Saint Petersburg, Russia; \\ yury.koshtyal@gmail.com (Y.K.); carlemeros@gmail.com (I.M.); dennazar1@ya.ru (D.N.); \\ medvedev.os1990@gmail.com (O.M.); artem_7.kim@mail.ru (A.K.); iezhov1994@gmail.com (I.E.); \\ rumyantsev.amr@gmail.com (A.R.); director@immet.spbstu.ru (A.P.) \\ 2 Saint Petersburg State University, 199034 Saint Petersburg, Russia \\ 3 Ioffe Institute, 194021 Saint Petersburg, Russia \\ * Correspondence: maximspbstu@mail.ru
}

check for updates

Citation: Koshtyal, Y.; Mitrofanov, I.; Nazarov, D.; Medvedev, O.; Kim, A.; Ezhov, I.; Rumyantsev, A.; Popovich, A.; Maximov, M.Y. Atomic Layer Deposition of Ni-Co-O Thin-Film Electrodes for Solid-State LIBs and the Influence of Chemical Composition on Overcapacity. Nanomaterials 2021, 11, 907. https://doi.org/10.3390/ nano11040907

Academic Editors:

Christophe Detavernier and Nina V. Kosova

Received: 11 March 2021

Accepted: 31 March 2021

Published: 2 April 2021

Publisher's Note: MDPI stays neutral with regard to jurisdictional claims in published maps and institutional affiliations.

Copyright: (C) 2021 by the authors Licensee MDPI, Basel, Switzerland. This article is an open access article distributed under the terms and conditions of the Creative Commons Attribution (CC BY) license (https:// creativecommons.org/licenses/by/ $4.0 /)$.

\begin{abstract}
Nanostructured metal oxides (MOs) demonstrate good electrochemical properties and are regarded as promising anode materials for high-performance lithium-ion batteries (LIBs). The capacity of nickel-cobalt oxides-based materials is among the highest for binary transition metals oxide (TMOs). In the present paper, we report the investigation of Ni-Co-O (NCO) thin films obtained by atomic layer deposition (ALD) using nickel and cobalt metallocenes in a combination with oxygen plasma. The formation of NCO films with different ratios of Ni and Co was provided by ALD cycles leading to the formation of nickel oxide (a) and cobalt oxide (b) in one supercycle (linear combination of $\mathrm{a}$ and $\mathrm{b}$ cycles). The film thickness was set by the number of supercycles. The synthesized films had a uniform chemical composition over the depth with an admixture of metallic nickel and carbon up to 4 at.\%. All samples were characterized by a single NixCo1-xO phase with a cubic face-centered lattice and a uniform density. The surface of the NCO films was uniform, with rare inclusions of nanoparticles 15-30 nm in diameter. The growth rates of all films on steel were higher than those on silicon substrates, and this difference increased with increasing cobalt concentration in the films. In this paper, we propose a method for processing cyclic voltammetry curves for revealing the influence of individual components (nickel oxide, cobalt oxide and solid electrolyte interface-SEI) on the electrochemical capacity. The initial capacity of NCO films was augmented with an increase of nickel oxide content.
\end{abstract}

Keywords: atomic layer deposition; nickel-cobalt oxide; anode materials; solid-state Li-ion batteries; overcapacity; SEI

\section{Introduction}

Small-sized power sources, with large cyclic capability and high energy density, such as solid-state lithium-ion batteries (SSLIB), are in demand owing to rapidly developing technologies including the Internet of Things (IoT). The IoT concept involves the use of a large number of wireless miniature devices (sensors [1], activators, real-time clocks [2], etc.), which require the implementation of the energy harvesting principle [3] to ensure their autonomous operation.

SSLIBs offer the following advantages over lithium-ion batteries (LIBs) with liquid electrolytes: increased fire safety, long-term static and dynamic stability without selfdischarge and long service life [4,5], unlike LIBs with liquid electrolytes. In addition, in SSLIBs it is possible to increase the charge voltage and the voltage of the battery itself, making it possible to increase the energy density [4,5]. 
Binary transition metal oxides (TMOs), owing to their high capacity (e.g., $\mathrm{ZnFeO}_{2}-$ $700 \mathrm{mAh} / \mathrm{g}, \mathrm{ZnCo}_{2} \mathrm{O}_{4}-867 \mathrm{mAh} / \mathrm{g}, \mathrm{NiCoO}_{2}-716 \mathrm{mAh} / \mathrm{g}, \mathrm{NiCo}_{2} \mathrm{O}_{4}-891 \mathrm{mAh} / \mathrm{g}$ ), are very promising materials for producing SSLIB anodes. However, low conductivity and relatively high-volume change during cycling are the main challenges limiting their use [6,7]. To overcome these challenges, it is necessary to utilize various nanostructures that are more stable with repeated cycling than bulk materials of anodes [6,8,9]. Moreover, 2-D nanostructures, called nanofilms, can be used for producing thin-film SSLIBs to minimize the size of electronic devices.

Thin-film components (cathodes, anodes, solid electrolytes) can be manufactured using atomic layer deposition (ALD), chemical vapor deposition (CVD), pulsed laser deposition (PLD), magnetron sputtering, and others [10-12]. Among these methods, ALD is the most promising since it allows the synthesis of uniform and conformal films of various materials on flat and 3-D substrates of complex shapes [13,14]. In this case, it is possible to control the thickness of the deposited coatings with high precision.

Numerous studies have addressed the preparation of individual components of thin-film SSLIBs by ALD, such as cathodes [15-26], anodes [27-49] and solid-state electrolytes [50-53]. Using several precursors in the ALD chamber allows the fabrication of all the SSLIB components using ALD equipment [12]. However, thin-film materials based on binary TMOs of nickel and cobalt $\left(\mathrm{NiCO}_{2} \mathrm{O}_{4}\right.$ and $\left.\mathrm{NiCoO}_{2}\right)$ fabricated by ALD [54] have not been studied as LIB anodes.

The aim of this work was to prepare thin-film anodes of binary TMOs of nickel and cobalt by ALD using different ratios of pulses of metal-containing precursors. In addition to studying the composition, morphology and crystallinity of the deposited films, special attention was paid to characterizing the electrochemical properties.

Previously, we showed an increase in the electrochemical activity of $\mathrm{NiO}$ anodes caused by an increase in the electrochemical activity of the SEI (solid electrolyte interphase) films [55]. In this regard, the method for determining the capacity in disk cells using an electrolyte may be inaccurate due to the SEI contribution to the measured capacity. In addition, the growth rate of SEI films can depend on the nature of the anode material, which introduces additional uncertainty in the characteristics of the films under study. Fabricating multilayer structures of solid-state thin-film LIBs is a difficult task and the determining characteristics of active materials (anodes) can be limited by other system components such as the solid electrolyte and cathode. Therefore, within the framework of the described research objectives, an attempt was made to separate the various components in the results of electrochemical testing in a liquid electrolyte.

\section{Materials and Methods}

Monocrystalline silicon substrates (surface orientation (100), $40 \times 40 \mathrm{~mm}$, TelecomSTV Co., Ltd., Zelenograd, Russia) and stainless-steel plates (316SS, 16 mm diameter, Tob New Energy Technology Co., Ltd., Xiamen, China) were used as substrates for ALD. Prior to deposition, the silicon and stainless-steel substrates were cleaned in an ultrasonic bath in acetone and deionized water for 10 and $5 \mathrm{~min}$, respectively. To remove the native silicon oxide layer, the silicon substrates were immersed for $5 \mathrm{~min}$ in $10 \%$ hydrofluoric acid solution(HF). Then, silicon substrates were cleaned using piranha solution $\left(\mathrm{H}_{2} \mathrm{SO}_{4} / \mathrm{H}_{2} \mathrm{O}_{2}\right.$, volume ratio 7:3) for 20 min to remove organic contaminants and produce a hydroxylic surface. Finally, the silicon substrates were rinsed in deionized (DI) water and dried under an argon atmosphere [29].

ALD of nickel-cobalt oxide (NCO), nickel oxide (NO), and cobalt oxide (CO) were performed with a commercial R-150 setup (Picosun Oy, Espoo, Finland) at a temperature of $300{ }^{\circ} \mathrm{C}$ and a reactor base pressure of 8-12 hPa. Bis(cyclopentadienyl) nickel(II) and Bis(cyclopentadienyl) cobalt(II) (Ni(Cp) $)_{2} \mathrm{Co}(\mathrm{Cp})_{2} ; 99 \%$, Dalchem, Nizhny Novgorod, Russia) were used as the nickel and cobalt-containing precursors. $\mathrm{Co}(\mathrm{Cp})_{2}$ and $\mathrm{Ni}(\mathrm{Cp})_{2}$ were kept in stainless-steel bottles (Picohot ${ }^{\mathrm{TM}}$ 200, Picosun Oy) and heated during deposition to 160 and $110^{\circ} \mathrm{C}$, respectively. The pulse times and purge times were $1 \mathrm{~s}$ and $10 \mathrm{~s}$ for both 
$\mathrm{Co}(\mathrm{Cp})_{2}$ and $\mathrm{Ni}(\mathrm{Cp})_{2}$. Remote oxygen plasma was used as a counter-reagent. The plasma power was $3 \mathrm{~kW}$, with a frequency range of 1.9-3.2 MHz. The total plasma pulse time was $19.5 \mathrm{~s}$ (Ar purge during $0.5 \mathrm{~s}$ with flow rate $40 \mathrm{sccm}$; Ar and $\mathrm{O}_{2}$ plasma purge during $14 \mathrm{~s}$ with flow rate $90 \mathrm{sccm}$; Ar purge during $5 \mathrm{~s}$ with flow rate $40 \mathrm{sccm}$ ). Deposition conditions were based on our previous studies devoted to obtaining cobalt and nickel oxide $[55,56]$.

The spectroscopic ellipsometry parameters $(\Psi$ and $\Delta)$ for films deposited on a silicon substrate were measured out with an Ellips-1891 SAG ellipsometer (CNT, Novosibirsk, Russia) in a wavelength range from 370 to $1000 \mathrm{~nm}$ and an incidence angle of $70^{\circ}$. The Spectr software package (1.10, CNT, Novosibirsk, Russia) was used to construct and fit a structural-optical model function. After fitting the parameters of the optical model and experimental spectra, the thicknesses of the films were calculated. The errors of the film thickness calculation were no more than $0.3 \mathrm{~nm}$. The gradient of the thickness (GT) was calculated using Equation (1):

$$
G T=\frac{\mathrm{T}_{\max }-\mathrm{T}_{\min }}{\mathrm{T}_{\max }+\mathrm{T}_{\min }} \times 100 \%,
$$

where $\mathrm{T}_{\max }$ and $\mathrm{T}_{\min }$ are the maximum and minimum film thicknesses, respectively [29].

$X$-ray reflectometry (XRR) and X-ray diffraction (XRD) studies were performed with a Bruker D8 DISCOVER $(\mathrm{Cu}-\mathrm{K} \alpha=1.5406 \AA)$ diffractometer. Surface-sensitive grazing incidence XRD (GIXRD) modes were used for XRD measurements using a $2 \theta$ range of $30-65^{\circ}$ with a step of $0.1^{\circ}$ and an exposure of $1 \mathrm{~s}$ at each step. The incidence angle of the primary X-ray beam was $0.7^{\circ}$. XRR measurements were performed in an angle range of $0.3-5^{\circ}$ (increment $0.01^{\circ}$ ) using symmetric scattering geometry. The obtained results were processed by the Rietveld method using the TOPAS software package (ver. 5, Bruker, Billerica, MA, USA) and by the simplex method using the LEPTOS (ver. 7.7, Bruker, Billerica, MA, USA) for XRD and XRR, respectively.

X-ray photoelectron spectra (XPS) were acquired with an Escalab 250Xi spectrometer (Thermo Fisher Scientific, Waltham, MA, USA). The samples were sputtered by $\mathrm{Ar}^{+}$ions with an energy of $500 \mathrm{eV}$ for 30 and 45 or $90 \mathrm{~s}$. The samples were excited by Al-K $\alpha$ $(1486.7 \mathrm{eV}) \mathrm{X}$-rays at a pressure of $7 \times 10^{-8} \mathrm{~Pa}$.

Scanning electron micrographs of planar and cross-sectional views were obtained by a Supra 55 VP scanning electron microscope (SEM, Zeiss, Oberkochen, Germany) with a Gemini-I column and a field emission cathode. Spatial resolution was about $1.3 \mathrm{~nm}$ at an accelerating voltage of $15 \mathrm{kV}$. A total of 3-4 randomly selected positions on the surface of the sample were investigated. Everhart-Thornley and InLens secondary electron detectors were used for SEM studies. Energy-dispersive X-ray (EDX) analysis was performed using the INCA X-Max system (Oxford Instruments, High Wycombe, UK) installed on the SEM Supra 55 VP.

Stainless-steel plates with deposited films were used for electrochemical studies. Lithium foil, polyolefin porous film 2325 (Celgard, Charlotte, NC, USA), and TC-E918 (Tinci, Guangzhou, China) solutions were used as the counter, separator, and electrolyte, respectively. The composition of TC-E918 was a $1 \mathrm{M}$ solution of $\mathrm{LiPF}_{6}$ in a mixture of organic carbonates (ethylene carbonate, propylene carbonate, diethyl carbonate, ethyl methyl carbonate, vinylene carbonate). The coin cells (CR2032) were assembled in an argon atmosphere using an OMNI-LAB glove box (VAC). Cyclic voltammetry (CV) was performed using a PGSTAT302N+ potentiostat (Autolab, Utrecht, The Netherlands) in a range of $0.01-3.00 \mathrm{~V}$ with a scan rate of $0.5 \mathrm{mV} / \mathrm{s}$. Discharge tests at different current densities were run with a CT3008W-5V10mA charge/discharge stand (Neware, Shenzhen, China), calibrated to work with low currents in a voltage range from $3.00 \mathrm{~V}-0.01 \mathrm{~V}$, and current densities of 10, 20,40,80,160,320,480,640,800 $\mu \mathrm{A} / \mathrm{cm}^{2}$. Deconvolution of the CV patterns was performed using the Origin (ver. 9.0.0) software package. 


\section{Results and Discussion}

\subsection{Atomic Layer Deposition of Ni-Co-O Thin Films}

First, we determined the conditions for ALD of oxide systems $(\mathrm{NiO}, \mathrm{CoO})$ based on previous experience [55,57], as shown in Table 1 . The optimal temperature of the reactor was $300^{\circ} \mathrm{C}$, and for stainless-steel bottles with $\mathrm{NiCp}_{2}$ and $\mathrm{CoCp}_{2}$, the optimal temperatures were 110 and $150^{\circ} \mathrm{C}$, respectively. The pulse times of the metal-containing reagent(A) and oxygen plasma(B) were 1 and $15 \mathrm{~s}$, respectively, for both processes.

Table 1. Conditions for atomic layer deposition (ALD) of Ni and Co oxides synthesis.

\begin{tabular}{ccccccc}
\hline $\begin{array}{c}\text { Deposited } \\
\text { Oxides }\end{array}$ & Reagent & $\begin{array}{c}\text { Co- } \\
\text { Reactant }\end{array}$ & $\begin{array}{c}\text { Pulse/Purge } \\
\text { Times, Sec } \\
\mathbf{t}_{\mathbf{1}} / \mathbf{t}_{\mathbf{2}} / \mathbf{t}_{\mathbf{3}} / \mathbf{t}_{\mathbf{4}}\end{array}$ & $\begin{array}{c}\text { Reagent } \\
\text { Temperature, } \\
{ }^{\circ} \mathbf{C}\end{array}$ & $\begin{array}{c}\text { Reactor } \\
\text { Temperature, } \\
{ }^{\circ} \mathbf{C}\end{array}$ & $\begin{array}{c}\text { GPC } \\
\text { A/Cycle }\end{array}$ \\
\hline $\mathrm{NiO}$ & $\mathrm{NiCp}_{2}$ & $\mathrm{O}_{2}$ plasma & $1 / 10 / 15 / 5$ & 110 & 300 & 0.12 \\
$\mathrm{CoO}$ & $\mathrm{CoCp}_{2}$ & & 150 & 300 \\
\hline
\end{tabular}

Note: $t_{1}$-pulse time of metal-containing reagent, $t_{2}, t_{4}$-purge time of the reactor by nitrogen combined with evacuation, after reagent pulse of $A$ and $B$, respectively, $t_{3}$ — surface treatment time with precursor $B$, GPC — growth per cycle.

To prepare binary TMOs using ALD, we used the supercycle approach. This approach takes the common binary ALD cycles of precursor and coreactant pulses for each constituent process and combines them into a cycle of cycles [58]. In the $\mathrm{NiCoO}_{2}$ phase, the ratio $\mathrm{Ni} / \mathrm{Co}=1$; therefore, we used the ratio of the cycles of obtaining $\mathrm{NiO}$ and $\mathrm{CoO}$ in one supercycle, which is also equal to 1 . However, given that growth per cycle (GPC) for $\mathrm{CoO}$ $(0.22 \AA)$ was almost twice the increase per cycle for $\mathrm{NiO}(0.12 \AA)$, we also synthesized samples with a large number of $\mathrm{NiO}$ cycles in one supercycle (Table 2).

Table 2. Transition metal oxide (TMO) films thickness and growth per cycle/supercycle measurement/calculation.

\begin{tabular}{|c|c|c|c|c|c|c|c|c|c|c|c|c|}
\hline \multirow[t]{2}{*}{ Sample } & \multicolumn{2}{|c|}{$\begin{array}{c}\text { Ratio of } \\
\text { Cycles }\end{array}$} & \multirow{2}{*}{$\begin{array}{c}\text { Number of } \\
\text { Cycles/Supercycles }\end{array}$} & \multicolumn{3}{|c|}{ Ellipsometry, Å } & \multicolumn{3}{|c|}{$\mathrm{XRR}, \AA$} & \multicolumn{3}{|c|}{ Calculation, Å } \\
\hline & $\mathrm{NiO}$ & $\mathrm{CoO}$ & & h & GPSC & GPC & h & GPSC & GPC & h & GPSC & GPC \\
\hline $\mathrm{NO}$ & 1 & 0 & 2308 & 272 & - & 0.12 & 280 & - & 0.12 & - & - & - \\
\hline NCO-5/1 & 5 & 1 & $310 / 1860$ & 284 & 0.92 & 0.15 & 261 & 0.84 & 0.15 & 254 & 0.82 & 0.14 \\
\hline $\mathrm{NCO}-3 / 1$ & 3 & 1 & $470 / 1880$ & 338 & 0.72 & 0.18 & 300 & 0.64 & 0.16 & 273 & 0.58 & 0.15 \\
\hline NCO-1/1 & 1 & 1 & $900 / 1800$ & 346 & 0.38 & 0.19 & 322 & 0.36 & 0.18 & 306 & 0.34 & 0.17 \\
\hline $\mathrm{CO}$ & 0 & 1 & 500 & 110 & - & 0.22 & 174 & - & 0.34 & - & - & - \\
\hline
\end{tabular}

Note: $\mathrm{NO}-\mathrm{NiO}, \mathrm{NCO}-$ Nickel-cobalt Oxide, $\mathrm{CO} —$ Cobalt Oxide, h—thickness.

The thicknesses of the films on silicon substrates were measured using spectroscopic ellipsometry and XRR. The XRR curves are represented in supplement materials (Figures S1-S5). The growth per cycle (GPC) and per supercycle (GPSC) are presented in Table 2. The XRR data showed slightly lower values than ellipsometry data. Based on the GPC values obtained from ellipsometry for pure $\mathrm{NiO}$ and $\mathrm{CoO}$, the thicknesses, GPC, and GPSC were calculated for the binary TMO samples (Table 2). These calculations assumed that the GPC of $\mathrm{NiO}$ and $\mathrm{CoO}$ remained constant when going from standard cycles to supercycles. The calculated values turned out to be $10-20 \%$ less than the experimental ones, which indicates the stimulation of the growth of one or both phases on the surface of the other when using supercycles.

\subsection{Chemical Composition of the Films}

XPS and SEM-EDX were used to determine the chemical composition of the samples. Measurements of XPS spectra were made after sputtering of the surface layer using the argon ions $(3 \mathrm{keV})$. To determine homogeneity of a chemical composition, different sputtering times were used (0,30 and 45 or 90 s). Results of XPS without sputtering showed high 
carbon content $(>20 \%)$ due to adventation carbon contamination. After sputtering, the carbon content decreased remarkably to $2-4 \%$ depending on the type of sample (Table 3 ).

Table 3. Chemical composition of NO, CO and NCO samples deposited on silicon supports based on $\mathrm{X}$-ray photon electron spectra (XPS) data.

\begin{tabular}{|c|c|c|c|c|c|c|c|}
\hline \multirow{2}{*}{ Sample } & \multirow{2}{*}{$\begin{array}{l}\text { Sputtering } \\
\text { Time, s }\end{array}$} & $\mathrm{C}$ & $\mathrm{O}$ & $\mathrm{Ni}$ & Co & $\mathrm{Ni}+\mathrm{Co}-\mathrm{O}$ & \multirow{2}{*}{$\mathrm{Ni} / \mathrm{Co}$} \\
\hline & & \multicolumn{5}{|c|}{ at. $\%$} & \\
\hline $\mathrm{NO}$ & 90 & 1.7 & 43.3 & 55.0 & 0 & 55.0 & - \\
\hline NCO-5/1 & 90 & 3.8 & 43.4 & 35.1 & 17.6 & 9.3 & 1.99 \\
\hline $\mathrm{NCO}-3 / 1$ & 90 & 3.2 & 42.9 & 23.1 & 30.8 & 10.9 & 0.75 \\
\hline NCO-1/1 & 90 & 3.5 & 47.1 & 7.5 & 41.9 & 2.4 & 0.18 \\
\hline $\mathrm{CO}$ & 45 & 3.9 & 45.3 & 0 & 50.7 & 5.3 & - \\
\hline
\end{tabular}

In the C1s spectra (Figure 1a), for all samples and regardless of the sputtering time, only one peak (maxima at $284.8 \mathrm{eV}$ ) was clearly visible, corresponding to the carbon of the $\mathrm{C}-\mathrm{C}$ and $\mathrm{C}-\mathrm{H}$. The carbon was likely from cyclopentadienyl nickel and cobalt, which can thermally decompose at the temperatures required for ALD [59]. In general, the peak with a maximum at $284.8 \mathrm{eV}$ was symmetric. No additional peaks in the range of $287-292 \mathrm{eV}$, corresponding to carbon found in various oxygen-containing groups (hydroxyl, aldehyde, carboxyl etc.) were observed.
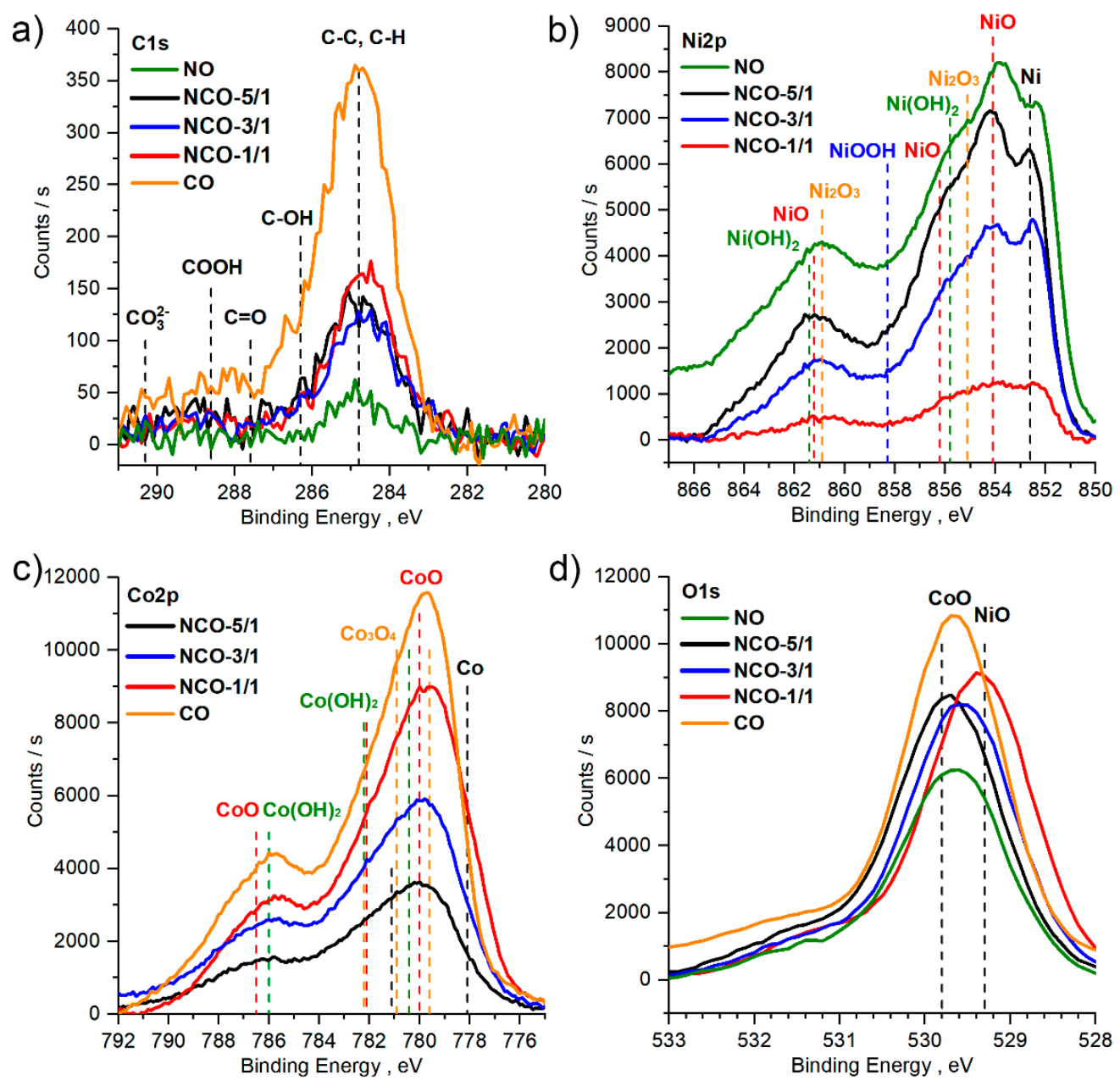

Figure 1. X-ray photoelectron spectra after Ar+ ion-sputtering during $90 \mathrm{~s}$ for NO, NCO and 45 s for CO: (a) C1s, (b) O1s, (c) Ni2p, (d) Co2p. 
The spectrum for Ni2p (Figure 1b) was complex because of the significant overlap of the Ni3d and O2p orbitals, resulting in broad peaks with multiple satellite peaks [59-61]. However, the shape and position of the maxima showed that all the samples under study contain $\mathrm{NiO}(854.1 \mathrm{eV})$ and $\mathrm{Ni}^{+3}\left(\mathrm{Ni}_{2} \mathrm{O}_{3}\right.$ and $/$ or $\left.\mathrm{Ni}_{3} \mathrm{O}_{4}\right)$, or nickel hydroxide $-\mathrm{Ni}(\mathrm{OH})_{2}$. For all samples, a peak in the region with a maximum of $852.7 \mathrm{eV}$, corresponding to metallic nickel, was clearly visible. The formation of metallic nickel is caused by the decomposition of the initial precursor, a cyclopentadienyl nickel. This was observed in a number of other studies, including CVD using $\mathrm{Ni}\left(\mathrm{C}_{5} \mathrm{H}_{5}\right)_{2}$ and $\mathrm{O}_{2}$ as precursors [62].

The Co2p spectrum was also quite complex (Figure 1c), as it contained a combination of many components, and could not be decomposed into components with high accuracy and reliability. However, according to the position of the Co2p maxima both in the NCO series and in the $\mathrm{CO}$ sample, cobalt existed predominantly in the form of $\mathrm{CoO}$. However, the presence of metallic cobalt and / or $\mathrm{Co}_{3} \mathrm{O}_{4}$ in small amounts was also possible.

The oxygen content in the films varied between $41-47 \%$ and was slightly less than the total content of cobalt and nickel due to the presence of metallic nickel and possibly cobalt. The shape of the O1s spectra was similar for all samples (Figure 1d). The positions of the maxima for the samples $\mathrm{NO}(\mathrm{NiO}), 529.6 \mathrm{eV}$, and $\mathrm{CO}(\mathrm{CoO}), 529.7 \mathrm{eV}$, were nearly identical, are in agreement with the literature data $[63,64]$. However, a shift of the peaks towards lower energies was observed with decreasing nickel concentration, although the shift was small and the maxima of all peaks were in the range of 529.4-529.7 eV. Such small displacements can be caused by inaccuracies in charge compensation during the normalization of the spectra to the C1s line, which was very noisy for these samples (Figure 1a). It should also be noted that the content of elements and the shape of the corresponding spectra C1s, $\mathrm{O} 1 \mathrm{~s}, \mathrm{Ni2} \mathrm{p}, \mathrm{Co} 2 \mathrm{p}$ for different sputtering times did not differ significantly, indicating the homogeneity of the composition of the films over depth of the film.

\subsection{Crystal Structure}

Figure 2 shows the diffraction patterns of the samples obtained by the grazingincidence method. The broad diffraction peaks in the region of $37^{\circ}, 43^{\circ}$, and $63^{\circ}$ were characterized by a cubic structure with the space group Fm-3m. Narrow peaks at $33^{\circ}$ and in the range of $54-62^{\circ}$ were associated with defects in the crystal structure of silicon substrates. The absence of peaks at $31^{\circ}$ and $56^{\circ}$ indicated a gradual substitution of cobalt atoms for nickel atoms without the formation of intermediate oxide forms of spinel $\left(\mathrm{Ni}_{\mathrm{x}} \mathrm{Co}_{1-\mathrm{x}}\right)_{3} \mathrm{O}_{4}$ (PDF 00-042-1467), which were observed in [54]. Thus, the phase composition of the samples was characterized by a single $\mathrm{Ni}_{x} \mathrm{Co}_{1-x} \mathrm{O}$ phase with a cubic face-centered lattice. The unit cell parameter refined by the Rietveld method for all samples is presented in Table 4 .

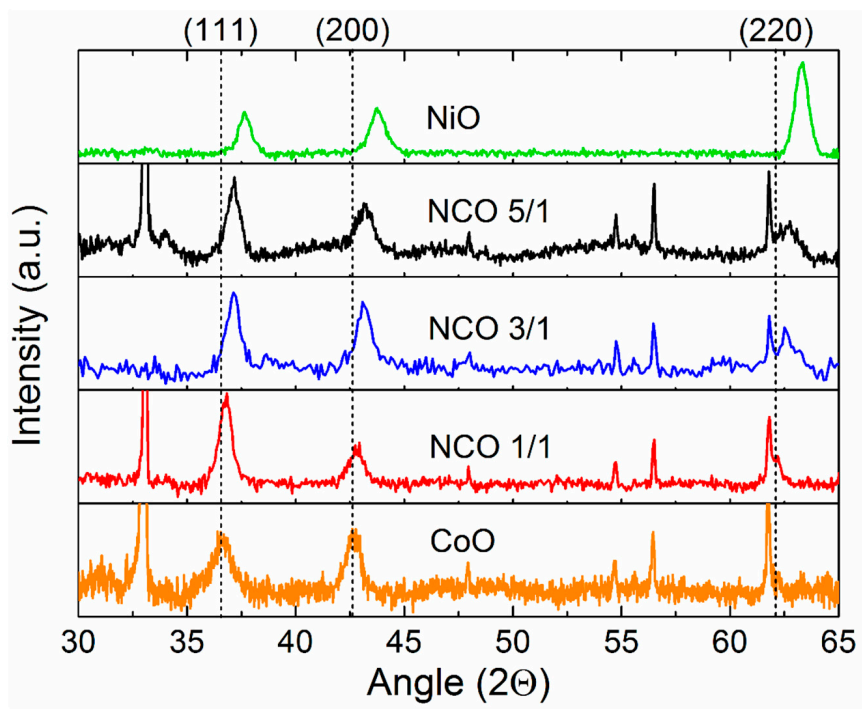

Figure 2. The X-ray diffraction patterns of the CoO, NCO-1/1, NCO-3/1, NCO-5/1, NiO thin films deposited on $\mathrm{Si}$. The dashed lines show the $\mathrm{CoO}$ peak positions. 
Table 4. Unit cell parameters, density and roughness of the TMOs thin films.

\begin{tabular}{cccc}
\hline Sample & $\boldsymbol{a}, \AA$ & Density, $\mathbf{g} / \mathbf{c m}^{\mathbf{3}}$ & Roughness, $\mathbf{n m}$ \\
\hline $\mathrm{NO}$ & 4.161 & 6.60 & 0.63 \\
$\mathrm{NCO}-5 / 1$ & 4.196 & 6.40 & 1.78 \\
$\mathrm{NCO}-3 / 1$ & 4.198 & 6.32 & 2.38 \\
$\mathrm{NCO}-1 / 1$ & 4.232 & 6.19 & 3.23 \\
$\mathrm{CO}$ & 4.245 & 6.31 & 1.12 \\
\hline
\end{tabular}

It can be seen from the results of X-ray diffraction analysis that with an increase in the $\mathrm{Ni}$ content in the $\mathrm{Ni}_{x} \mathrm{Co}_{1-\mathrm{x}} \mathrm{O}$ phase, the unit cell parameter decreased from 4.244 to $4.161 \AA$, which was reflected in a smooth shift of the positions of the peaks (111), (200), and (220) (in the XRD patterns, the dashed lines show CoO peak positions). The unit cell parameter of $\mathrm{NiO}$ and $\mathrm{CoO}$ films closely agreed with the data for compact materials $\mathrm{NiO}$ $(4.16 \AA)$ and $\mathrm{CoO}(4.24 \AA)$. As expected it increased with an increase in the proportion of $\mathrm{CoO}$ compared to NiO. From the ratio of the intensities of the peaks, a texture in the (111) direction was observed in the samples, which is typical for structures with a cubic system. The absence of reflections of metallic nickel, the presence of which was determined using XPS, may indicate its low fraction in the volume of the film or X-ray amorphousness due to the small size of crystallites.

According to XRR data (Table 4) obtained by the simplex method, all samples consisted of a uniform density layer with a roughness of 0.63 to $3.23 \mathrm{~nm}$. As the number of $\mathrm{NiCp}_{2}$ pulses in the supercycle decreased, the film density also decreased from 6.60 to $6.31 \mathrm{~g} / \mathrm{cm}^{3}$ (except for the NCO-1/1 sample), which was caused by a relative increase in the amount of the less dense $\mathrm{CoO}$ phase $\left(6.72 \mathrm{~g} / \mathrm{cm}^{3}\right.$ for $\mathrm{NiO}$ and $6.44 \mathrm{~g} / \mathrm{cm}^{3}$ for $\left.\mathrm{CoO}\right)$. The low density of thin films in comparison with compact oxides $\mathrm{NiO}$ and $\mathrm{CoO}$ was associated with a large influence of surface effects [55].

\subsection{Morphology of Films on Si and Steel Substrates}

Scanning electron microscopy images of $\mathrm{NiO}, \mathrm{NCO}-5 / 1, \mathrm{NCO}-3 / 1, \mathrm{NCO}-1 / 1$, and $\mathrm{CoO}$ films on Si substrate are presented in Figure 3. For the monoxide films ( $\mathrm{NiO}$ and $\mathrm{CoO}$ ), the surfaces were homogeneous and free of inclusions. Bright inclusions with a diameter of 10-13 nm (NCO-5/1, NCO-3/1) and 25-30 nm (NCO-1/1) were visible on the NCO film samples, as roughness increased in the series NCO-5/1-NCO-3/1-NCO- $1 / 1$, which is consistent with the XRR results (Table 4). It should be noted that the bright features of the NCO-1/1 sample were randomly directed nanowire crystals on the surface, the growth features of which will be discussed below.

The XPS results show that NCO films contained metallic nickel and, possibly, metallic cobalt as a result of the decomposition of precursors $\mathrm{NiCp}_{2}$ and $\mathrm{CoCp}_{2}$ [62]. It can be assumed that bright inclusions comparable with the film thickness were metallic particles of nickel and cobalt, a higher density of which gives an increased yield of secondary electrons that increases their contrast in comparison with the film.

Plan view and cross-section images of the studied films on stainless a steel substrate are shown in Figure 4. The general features of the film morphologies of silicon and steel were similar. As in the case of films on silicon, the growth rate increased with the cobalt content, though it should be noted that the thickness of the films on steel with simultaneous deposition process was greater, which indicates an increased growth rate of films on a steel substrate (see Table 5). Table 5 also presents the typical sizes of surface inclusions observed in NCO films on silicon (spectral ellipsometry results) and steel (SEM results).

It should be noted that, as in the case of NCO-1/1 on silicon, the film on steel was covered with randomly directed nanowire crystals, but their number was noticeably higher, which is most likely associated with a large number of crystallization centers and inhomogeneities on the steel substrate (due to the increased roughness) rather than silicon. On the cross-section view of the NCO- $1 / 1$ sample (Figure $4 \mathrm{~d}$ bottom), nanowire crystals can be easily observed, reaching lengths up to $40 \mathrm{~nm}$. Several mechanisms of the 
nanowire/whiskers growth are presented in the literature, describing the morphology of the sample NCO-1/1 [65-67], including the growth of metal-oxide whiskers [68-70]. During the formation of TMO nanowires, the importance of the chemical composition and growth conditions were noted $[69,70]$. Most likely, in the case of sample NCO-1/1, these two conditions were fulfilled, stimulating the growth of nanowire crystals on the surface. A more detailed discussion is presented in the Supplementary Materials.

SEM images of the $\mathrm{CoO}$ sample are presented in Figure 4e. The surface of the $\mathrm{CoO}$ film on the steel substrate was represented by large crystallites with diameters of $25-35 \mathrm{~nm}$, and small crystallites with diameters of 10-15 nm, similar to the features on the NCO-5/1 and NCO-3/1 samples.

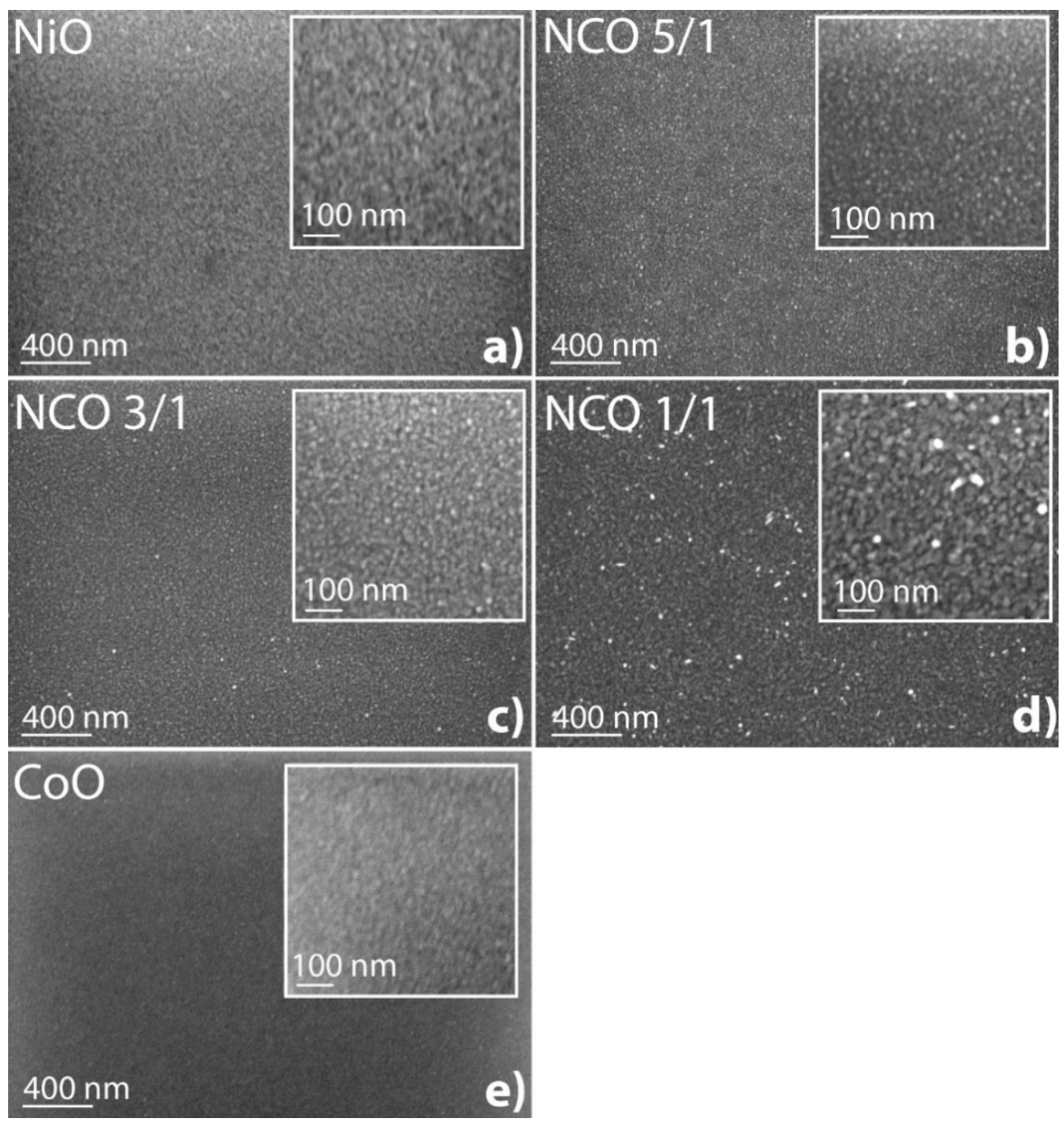

Figure 3. Scanning electron microscopy (SEM) images of (a) NiO, (b) NCO-5/1, (c) NCO-3/1, (d) NCO-1/1 and (e) CoO. thin films deposited on silicon.

Table 5. Film thickness on silicon and steel substrates, ratio, and the size of inclusions of studied TMO samples.

\begin{tabular}{cccccc}
\hline Sample & $\begin{array}{c}\text { Thickness on Si, } \\
\text { nm (Ellipsometry) }\end{array}$ & $\begin{array}{c}\text { Thickness } \\
\text { on Steel, } \\
\text { nm (SEM) }\end{array}$ & $\begin{array}{c}\text { Thickness on } \\
\text { Steel/Thickness } \\
\text { on Si }\end{array}$ & $\begin{array}{c}\text { Inclusion } \\
\text { Size on } \\
\text { Si, } \mathbf{~ n m}\end{array}$ & $\begin{array}{c}\text { Inclusion } \\
\text { Size on } \\
\text { Steel, } \mathbf{n m}\end{array}$ \\
\hline $\mathrm{NO}$ & 27 & $28-30$ & 1.1 & - & $15-20$ \\
$\mathrm{NCO}-5 / 1$ & 28 & $33-37$ & 1.2 & $10-13$ & $10-15$ \\
$\mathrm{NCO}-3 / 1$ & 34 & $42-47$ & 1.2 & $10-13$ & $10-15$ \\
$\mathrm{NCO}-1 / 1$ & 35 & $56-60$ & 1.8 & $25-30$ & $20-30$ \\
$\mathrm{CO}$ & 11 & 32 & 2.9 & - & $25-35$ \\
\hline
\end{tabular}




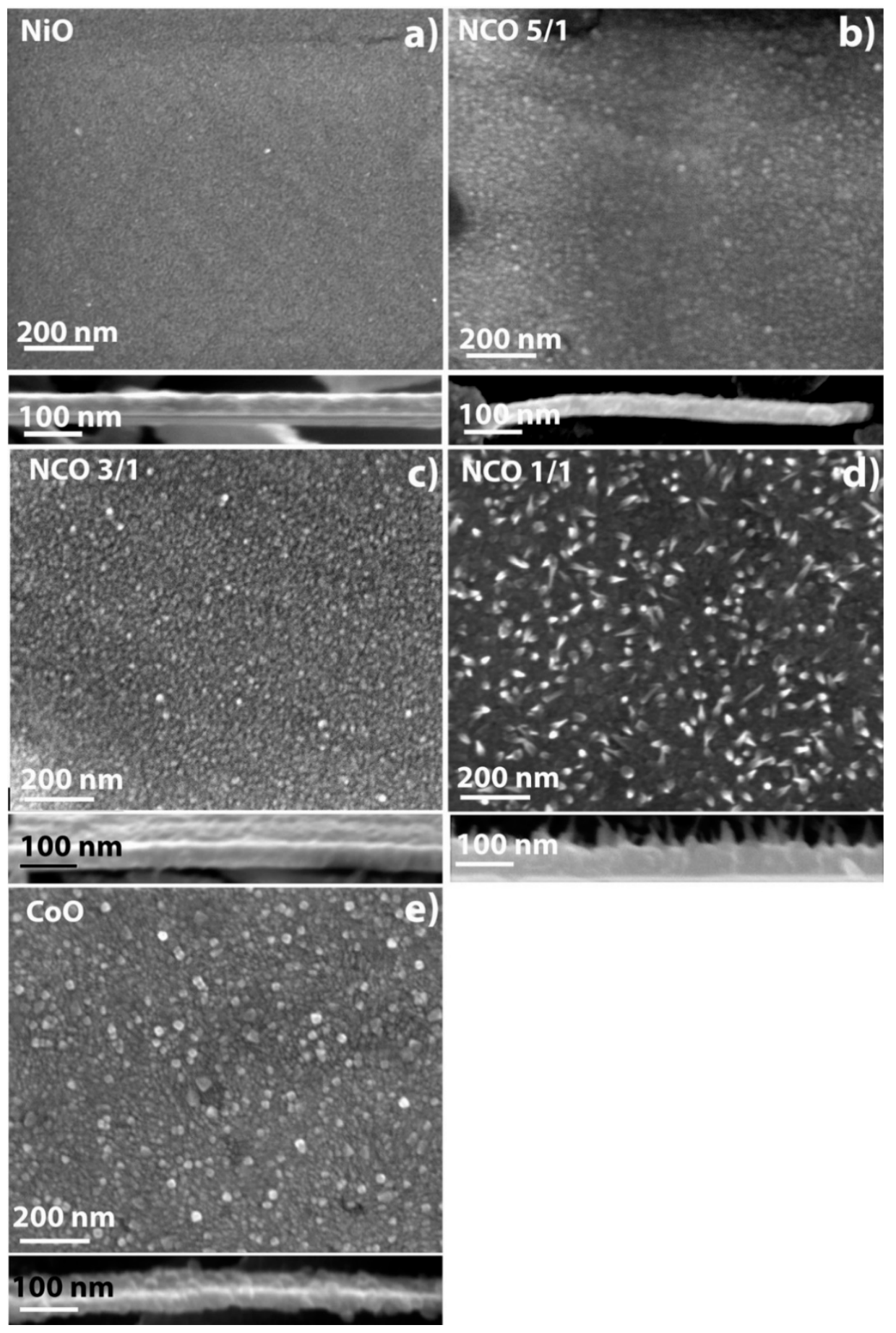

Figure 4. Scanning electron microscopy of plan view and cross section of the thin films deposited on steel: (a) NiO, (b) NCO-5/1, (c) NCO-3/1, (d) NCO-1/1 and (e) CoO.

\subsection{Electrochemical Studies}

Lithium metallic foil was used as a counter electrode during electrochemical studies of samples deposited on stainless steel. The current density varied from $10 \mu \mathrm{A} / \mathrm{cm}^{2}(\sim 0.3 \mathrm{C})$ to $800 \mu \mathrm{A} / \mathrm{cm}^{2}(\sim 33 \mathrm{C})$ (Figure 5). It was found that the charging capacities of investigated samples were stable during cycling at a given charge current density. The inset of Figure 5 shows typical charge-discharge curves at a current density of $40 \mu \mathrm{A} / \mathrm{cm}^{2}$ (approximately $1 \mathrm{C}$ ) in the potential range from 0 to $3 \mathrm{~V}$. The main contribution to the capacity during charging/discharging occurred at potentials of $1.5-2.2 \mathrm{~V} / 1.5-0.75 \mathrm{~V}$. 
According to XPS and XRD measurements, $\mathrm{CoO}, \mathrm{NiO}$, and $\mathrm{NiCoO}_{2}(\mathrm{Fm}-3 \mathrm{~m})$ phases were present in the deposited films, while spinel crystal phases of $\mathrm{Co}_{3} \mathrm{O}_{4}$ and $\mathrm{Ni}_{\mathrm{x}} \mathrm{Co}_{(1-\mathrm{x}) 3} \mathrm{O}_{4}$ were not. We calculated the specific capacities per unit mass and volume based on the assumed electrochemical processes occurring with detected phases (Equations (2)-(4)) and experimental data $[7,71-73]$. The results are summarized in Table 6.

$$
\begin{gathered}
\mathrm{NiCoO}_{2}+4 \mathrm{Li}^{+}+4 \mathrm{e}^{-} \rightarrow \mathrm{Ni}+\mathrm{Co}+2 \mathrm{Li}_{2} \mathrm{O}, \\
\mathrm{NiO}+2 \mathrm{Li}^{+}+2 \mathrm{e}^{-} \rightarrow \mathrm{Ni}+\mathrm{Li}_{2} \mathrm{O}, \\
\mathrm{CoO}+2 \mathrm{Li}^{+}+2 \mathrm{e}^{-} \rightarrow \mathrm{Co}+\mathrm{Li}_{2} \mathrm{O},
\end{gathered}
$$

As the discharge current increased from $0.3 \mathrm{C}$ to $33 \mathrm{C}$, the charge capacities decreased from 909-967 $\mu \mathrm{Ah} / \mathrm{cm}^{2} / \mu \mathrm{m}(1441-1460 \mathrm{mAh} / \mathrm{g})$ to $625-706 \mu \mathrm{Ah} / \mathrm{cm}^{2} / \mu \mathrm{m}(990-1140 \mathrm{mAh} / \mathrm{g})$. Such a moderate decrease in capacity $(21-33 \%)$, with a significant increment of current density, was apparently due to the small thickness of the electrochemically active films.

The measured capacities of thin-film electrodes were higher than the theoretical values and those found in the literature. Greater values for measured capacities over theoretical values for samples with similar chemical composition were also observed previously [7,71-73]. The difference between measured and theoretical capacities was likely caused by the additional capacity of an organic polymer film formed on the surface of the active material as a result of reactions between $\mathrm{Ni}$ and $\mathrm{Co}$ metal and electrolyte at electrode potentials below $0.4 \mathrm{~V}$ [7].

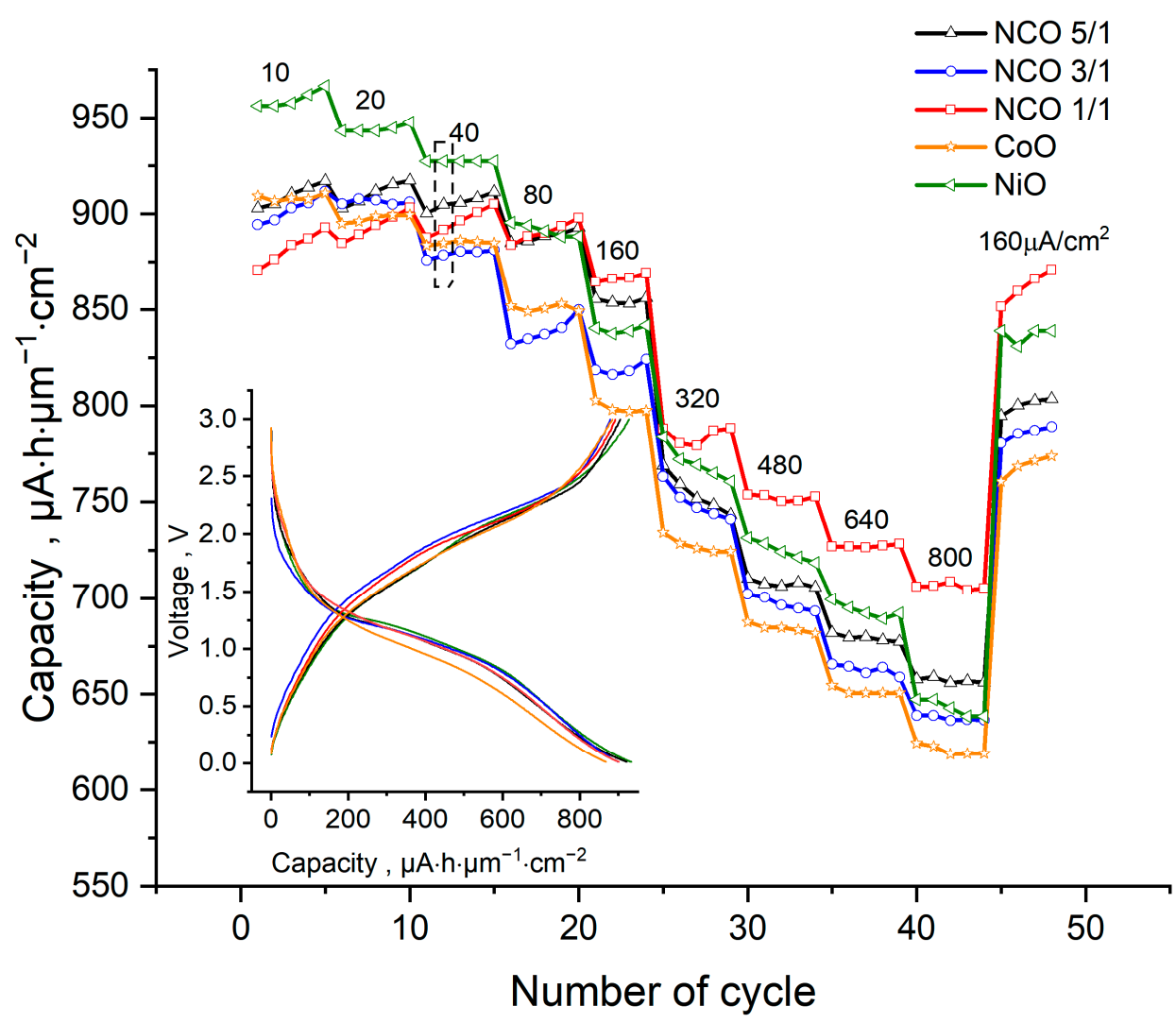

Figure 5. Rate performance and charge/discharge profile of the thin films. Charge/discharge curves are represented as dots in the dotted frame. 
Table 6. Specific capacities of TMOs.

\begin{tabular}{|c|c|c|c|c|c|}
\hline Active Material & Density, $\mathrm{g} / \mathrm{cm}^{3}$ & $\begin{array}{c}\text { Specific } \\
\text { Capacity, mAh/g }\end{array}$ & $\begin{array}{c}\text { Specific Volume } \\
\text { Capacity } \mu \mathrm{Ah} / \mathrm{cm}^{2} / \mu \mathrm{m}\end{array}$ & $\begin{array}{c}\text { Current Density, } \\
\mathrm{mA} / \mathrm{g}\left|\mu \mathrm{A} / \mathrm{cm}^{2}\right| \mathrm{C}-\text { Rate }\end{array}$ & Link Source \\
\hline $\mathrm{NiO}$ & 6.72 & 718 & 482.2 & - & \multirow{3}{*}{$\begin{array}{c}\text { Theoretical } \\
\text { (Faraday Law) }\end{array}$} \\
\hline $\mathrm{CoO}$ & 6.44 & 715 & 460.7 & - & \\
\hline $\mathrm{NiCoO}_{2}$ & $6.58 *$ & 717 & 471.4 & - & \\
\hline $\mathrm{NiO}$ thin films & 6.6 & $\begin{array}{c}1460 \\
981\end{array}$ & $\begin{array}{l}967 \\
647\end{array}$ & $\begin{array}{c}32|20| 0.3 \\
2550|800| 33\end{array}$ & \multirow{5}{*}{$\begin{array}{l}\text { This } \\
\text { Research }\end{array}$} \\
\hline $\begin{array}{l}\text { NCO-5/1 } \\
\text { thin films }\end{array}$ & 6.40 & $\begin{array}{l}1430 \\
1028\end{array}$ & $\begin{array}{l}917 \\
658 \\
\end{array}$ & $\begin{array}{c}32|20| 0.3 \\
2550|800| 33\end{array}$ & \\
\hline $\begin{array}{l}\mathrm{NCO}-3 / 1 \\
\text { thin films }\end{array}$ & 6.32 & $\begin{array}{l}1442 \\
1010\end{array}$ & $\begin{array}{l}912 \\
639\end{array}$ & $\begin{array}{c}32|20| 0.3 \\
2550|800| 33\end{array}$ & \\
\hline $\begin{array}{l}\mathrm{NCO}-1 / 1 \\
\text { thin films }\end{array}$ & 6.19 & $\begin{array}{c}1440 \\
1140.4\end{array}$ & $\begin{array}{l}893 \\
706 \\
\end{array}$ & $\begin{array}{c}32|20| 0.3 \\
2550|800| 33\end{array}$ & \\
\hline $\mathrm{CoO}$ thin films & 6.31 & $\begin{array}{c}1441.0 \\
990\end{array}$ & $\begin{array}{l}909 \\
625\end{array}$ & $\begin{array}{c}32|20| 0.3 \\
2550|800| 33\end{array}$ & \\
\hline $\begin{array}{c}\mathrm{NiCoO}_{2} \\
\text { Hierarchical } \\
\text { mesoporous } \\
\text { microspheres }\end{array}$ & $6.58 *$ & $\begin{array}{l}845 \\
397\end{array}$ & $\begin{array}{l}555.7 \\
261.0\end{array}$ & $\begin{array}{c}901-1- \\
4000 \mid-1-\end{array}$ & [7] \\
\hline $\begin{array}{l}\mathrm{NiCoO}_{2} \text { nanotubes } \\
\text { with Nanosheets }\end{array}$ & $6.58 *$ & $\begin{array}{c}1130 \\
300\end{array}$ & $\begin{array}{l}743.5 \\
197.4 \\
\end{array}$ & $\begin{array}{l}200 \mid-1- \\
800 \mid-1-\end{array}$ & [71] \\
\hline $\begin{array}{c}\mathrm{NiCoO}_{2} @ \mathrm{CNT} 1 \\
\text { Composites }\end{array}$ & $6.58 *$ & $\begin{array}{c}1150 \\
920\end{array}$ & $\begin{array}{l}756.7 \\
605.4 \\
\end{array}$ & $\begin{array}{l}2001-1- \\
8001-1-\end{array}$ & [71] \\
\hline $\begin{array}{c}\mathrm{NCO}_{2} \text { carbon fiber } \\
\text { nano-brushes }\end{array}$ & $6.58 *$ & $\begin{array}{c}1250 \\
300\end{array}$ & $\begin{array}{l}822.5 \\
197.4 \\
\end{array}$ & $\begin{array}{c}200 \mid-1- \\
2000|-|-\end{array}$ & {$[72]$} \\
\hline $\begin{array}{l}\mathrm{NiO}-\mathrm{CoO} \\
\text { nanosphere }\end{array}$ & $6.58 *$ & 1100 & 723.8 & $200 \mid-1-$ & {$[72]$} \\
\hline $\begin{array}{c}\text { Mesoporous } \\
\mathrm{CoNiO}_{2} \\
\text { hierarchical micro } \\
\text { flowers }\end{array}$ & $6.58 *$ & $\begin{array}{l}600 \\
200\end{array}$ & $\begin{array}{l}394.8 \\
131.6\end{array}$ & $\begin{array}{c}100|-|- \\
1000|-|-\end{array}$ & [73] \\
\hline
\end{tabular}

Note: ${ }^{1} \mathrm{CNT}$ - carbon nanotubes; ${ }^{2} \mathrm{NCO}-\mathrm{NiCoO}_{2},{ }^{*}$ the density of $\mathrm{NiCoO}_{2}$ was calculated based on $\mathrm{NiO}$ and $\mathrm{CoO}$ densities $(\mathrm{Table} 4)$.

At fixed current densities above $160 \mu \mathrm{A} / \mathrm{cm}^{2}(\sim 5 \mathrm{C})$, the charge capacities were augmented with additional nickel content in the deposited film. An exception to this trend was the NCO-1/1 sample, which exhibited the highest specific capacity $\left(870-706 \mu \mathrm{Ah} / \mathrm{cm}^{2} / \mu \mathrm{m}\right)$ ) at current densities of $160-800 \mu \mathrm{A} / \mathrm{cm}^{2}$. The observed superior capacity of the NCO-1/1 sample was likely due to the formation of whiskers during depositions, which have higher surface areas (Figure 4. SEM of steel).

Cyclic charge/discharge of electrodes resulted in a gradual increase in the discharge capacity. Wei et al. [72] (Figure 7c, AT curve) also observed capacity growth during cycling of active material with a similar chemical composition (NiO-CoO/carbon fiber). However, a detailed study of this phenomenon has not been found. The increase in capacity during cycling is likely directly related to the growth of SEI films and may depend on the nature of the anode material and the electrolyte used. Consequently, in the study of thin films' electrochemical properties, the contribution from SEI cannot be neglected, in contrast to the study of bulk anode/cathode materials. Considering the results of our previous studies on $\mathrm{NiO}$ films [55], cyclic voltammetry was applied to identify electrochemical processes occurring during the charging/discharging of nickel-cobalt mixed oxide films (Figure 6).

At the beginning of the CV study, the open circuit voltage was close to $3 \mathrm{~V}$. As the electrode potential gradually decreased, the conversion reaction was more likely to 
occur [74]. Furthermore, in the cathode area $(0.8-0.1 \mathrm{~V}$, with a maximum at $0.43 \mathrm{~V})$, a dramatic current increase was observed. A similar rise in current was observed when carbon materials were studied using electrolyte, signifying the reduction of the electrolyte components. With a subsequent increase in potential from 0 to $3 \mathrm{~V}$ in the anodic region, current peaks of 1.6-1.7 V and 2.0-2.3 V were observed, characterizing the changes of SEI film and transition metal oxides $(\mathrm{NiO}$ and $\mathrm{CoO})$, respectively (Figure $6 \mathrm{a}, \mathrm{c})$.

To understand the origin of current increment at 1.6-1.7 $\mathrm{V}$ of the anode curve, the effect of the potential width range on the form of the CV curve was studied using NCO-5/1 samples. For the first cycle, when the potential range was narrowed to $3.0-0.8 \mathrm{~V}$, the current increase of 1.6-1.7 V potential range of the cathode curve did not appear (Figure S6). Thus, the augmentation of current in the $0.8-0.1 \mathrm{~V}$ region (cathode curve) and in 1.6-1.7 V (anode curve) is connected and may be due to SEI film formation, which can significantly contribute to the reversible capacity. The transferred charge in $0.8-3.0 \mathrm{~V}$ and $0.1-3.0 \mathrm{~V}$ was $0.0709 \mathrm{C}$ (conversion reaction at $0.8-3.0 \mathrm{~V}$ ) and $0.321 \mathrm{C}$ (conversion reaction in $0.01-3.0 \mathrm{~V}$ range and SEI formation $0.01-0.8 \mathrm{~V}$ ). When cycling from $0.01 \mathrm{~V}$ to $3.0 \mathrm{~V}$ (first to ninth cycle), the cathode peak observed at $0.43 \mathrm{~V}$ (first cycle) shifted towards higher potentials up to $1.0 \mathrm{~V}$, signifying the transformation of the SEI film.

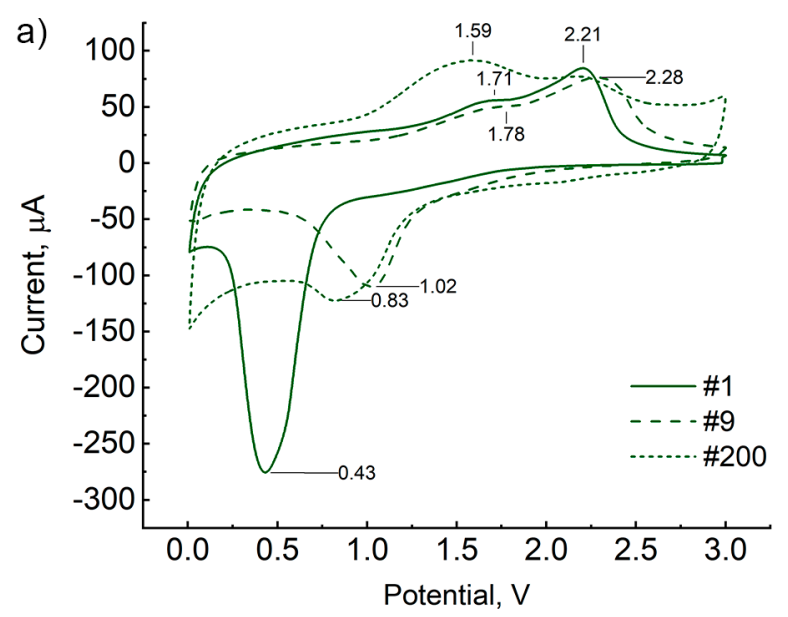

c)
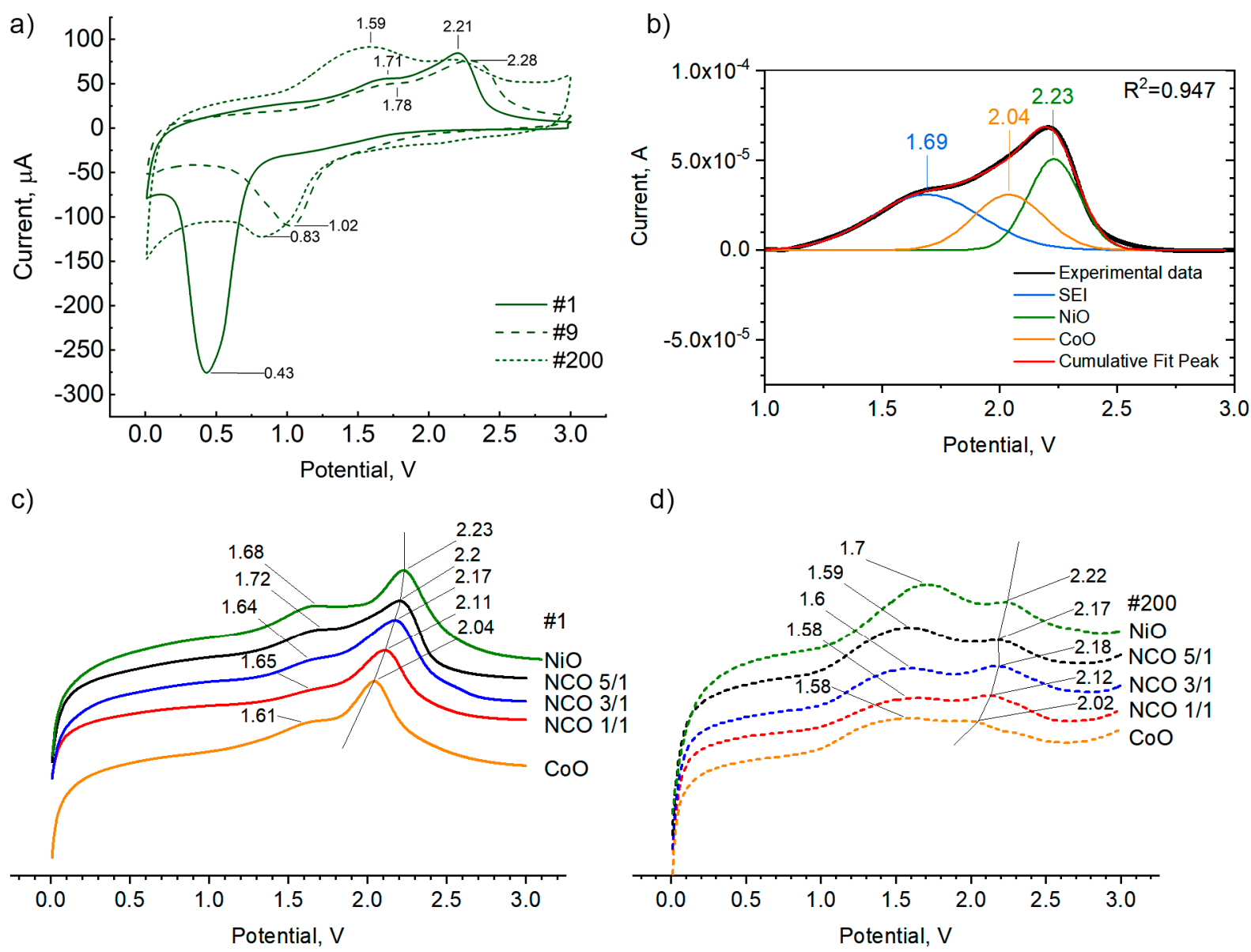

d)

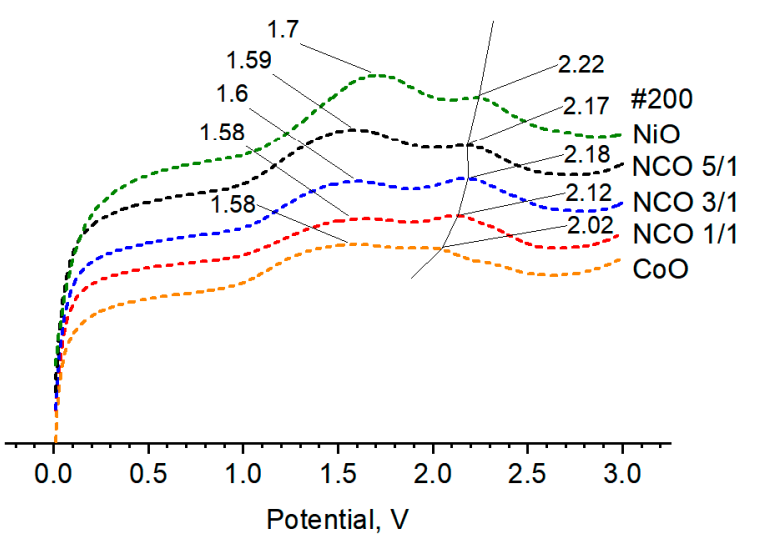

Figure 6. Cyclic voltammetry curves of the NCO-5/1 sample. (a) 1, 9 and 200 cycles, (b) example of deconvolution of the cyclic voltammetry (CV) curve of the NCO-5/1 sample, (c) anode CV curves of the films before, (d) after cycling (after 200 cycles) related to the thickness of the substrate. Presented curves for (c,d) plotted in the same coordinate system but physically spaced.

Performing 200 charge/discharge cycles in the $0.01-3.0 \mathrm{~V}$ potential range of the NCO5/1 sample resulted in a shift of the maximum from 1.6-1.7 $\mathrm{V}$ region towards lower potentials and an increase its intensity. Furthermore, specific capacity increased from 768 
to $833 \mu \mathrm{Ah} / \mathrm{cm}^{2} / \mu \mathrm{m}$ from 25 to 200 cycles, respectively (measured at $320 \mu \mathrm{A} / \mathrm{cm}^{2}$ for NCO-5/1 (Figure 6c,d).

After conducting 5 and 200 charge/discharge cycles, the NCO-5/1 electrodes were taken from CR2032 cases, then rinsed thoroughly with dimethyl carbonate (DMC) and investigated by scanning electron microscopy (Figure S7). It can be seen that on the surface of the NCO-5/1 electrode, after 200 charge/discharge cycles, a film of organic products of electrolyte decomposition was present and burned out by an electron beam (Figure S8). Considering SEM and CV investigations after a different number of cycles, it can be concluded that the current maximum at $1.6-1.7 \mathrm{~V}$ is related to SEI film, which was observed to grow during cycling.

To determine the influence of the chemical composition of the electrodes on the electrochemical activity, the shape of the anodic CV curves was analyzed (Figure $6 c, d$ ). The curves were normalized to the film thickness to allow for comparative analysis. With an increment of nickel oxide in films, a gradual shift in the maximum current intensity of the anodic curve from $2.04 \mathrm{~V}(\mathrm{CoO})$ to $2.23 \mathrm{~V}(\mathrm{NiO})$ and a change in the position of the maximum characterizing the SEI film from 1.6 to $1.7 \mathrm{~V}$ (Figure $6 \mathrm{c}$ ) were observed. The shift towards high potentials of the maxima characterizing the electrochemical activity of the SEI film and nickel and cobalt oxides, with an increase in the proportion of nickel oxide, persisted even after 200 charge/discharge cycles (Figure 6d). After 200 charge/discharge cycles, the intensity of the maximum characterizing the SEI film's electrochemical activity increased and became more significant than the total intensity of the maxima of nickel and cobalt oxides (Figure $6 c, d$ ).

Assuming that the increase of current observed on CV anode curves is proportional to electrochemical capacity and can be used to identify the contributions of the thin films' components to the electrochemical performance during cycling, we subtracted the baseline and deconvoluted the anode curves. For NCO films, the anodic curves were simulated by Gaussian curves with maxima of $2.02 \mathrm{~V}(\mathrm{CoO})$ and $2.23 \mathrm{~V}(\mathrm{NiO})$. The peak maxima positions were determined based on the $\mathrm{CV}$ curves of pure oxides obtained in this work at a potential scan rate of $0.5 \mathrm{mV} / \mathrm{s}$. The positions of maxima corresponding to the activity of $\mathrm{CoO}$ and $\mathrm{NiO}$ were fixed during modeling of $\mathrm{NCO}$ anode curves because they were retained even after cycling of $\mathrm{CoO}$ and $\mathrm{NiO}$ films during 200 cycles (Figure $6 \mathrm{c}, \mathrm{d}$ ). On the contrary, the position of the maximum revealing SEI activity was not fixed, since it changes during cycling. An example of Gaussian deconvolution for sample NCO-5/1 is shown in Figure $6 b$.

The change in the simulated Gaussian curve areas reflects the intensity of electrochemical processes in nickel oxide, cobalt oxide and SEI film, and characterizes the contribution of each component to the total electrochemical capacity (Figure 7).

The specific capacity in the initial charge/discharge cycles is mainly determined by the capacity of transition metal oxides ( $\mathrm{Ni}, \mathrm{Co}$ ). The smallest $\mathrm{SEI}$ film formation was observed for the NCO-3/1 coating, where nearly $80 \%$ of the capacity was electrochemical processes involving nickel and cobalt oxides; for the other compositions, this figure was closer to $60 \%$ (Figure 7a).

After subtraction of SEI film capacity from the total, the following values of deposited transition metal oxide films were obtained: $\mathrm{NiO}-538 \mu \mathrm{Ah} / \mathrm{cm}^{2} / \mu \mathrm{m}$; NCO$5 / 1-581 \mu \mathrm{Ah} / \mathrm{cm}^{2} / \mu \mathrm{m} ; \mathrm{NCO}-3 / 1-729 \mu \mathrm{Ah} / \mathrm{cm}^{2} / \mu \mathrm{m} ; \mathrm{NCO}-1 / 1-539 \mu \mathrm{Ah} / \mathrm{cm}^{2} / \mu \mathrm{m}$; $\mathrm{CoO}-568 \mu \mathrm{Ah} / \mathrm{cm}^{2} / \mu \mathrm{m}$. The calculated values of TMO films at the initial cycles approached the theoretical values (Table 6).

After conducting 200 charge/discharge cycles, it can be seen that the area characterizing nickel oxide activity decreased slightly for all coating compositions. A more noticeable decrease in electrochemical activity was observed for cobalt oxide. The area under the curve characterizing the SEI film increased significantly for all considered coating compositions. The SEI film's capacity became comparable to the capacity of TMOs (Figure 7b). For electrodes with monoxides $(\mathrm{CoO}$ and $\mathrm{NiO})$ due to the formed SEI film, the largest increase in capacity was noted. For electrodes with the NCO-1/1 composition, a significant 
increase in capacity due to the SEI was also observed, presumably due to the different morphology of the films and the presence of whisker nanocrystals (Figure $4 \mathrm{~b}$ ). It should be noted that the contribution to the capacity of cobalt oxide decreased after cyclic tests for all compositions. Samples of the NCO-3/1 and NCO-5/1 series were characterized by the lowest SEI contribution to the total capacity.

a)

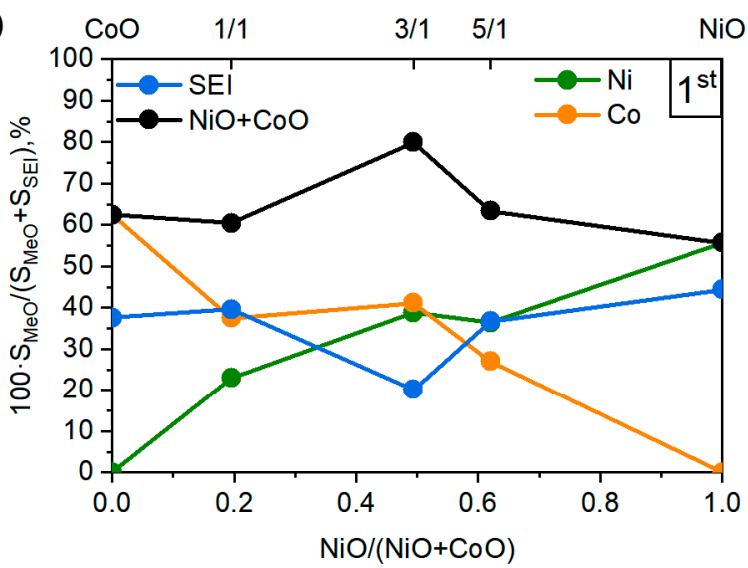

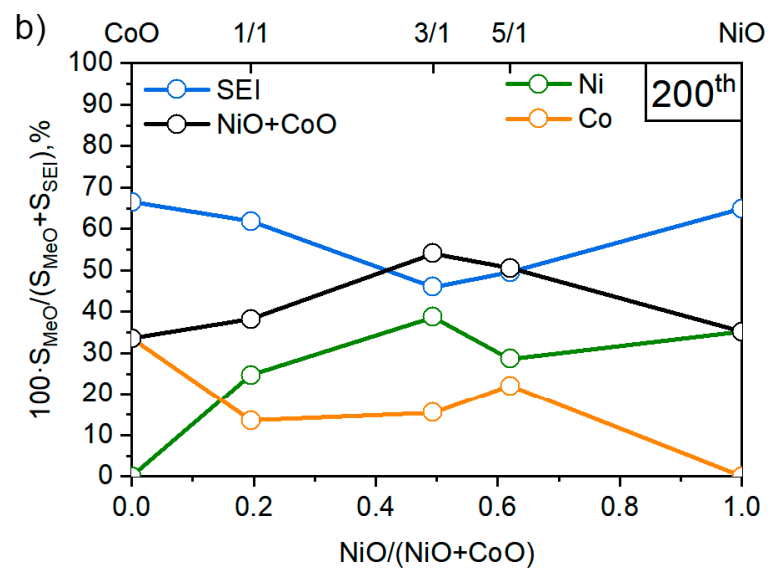

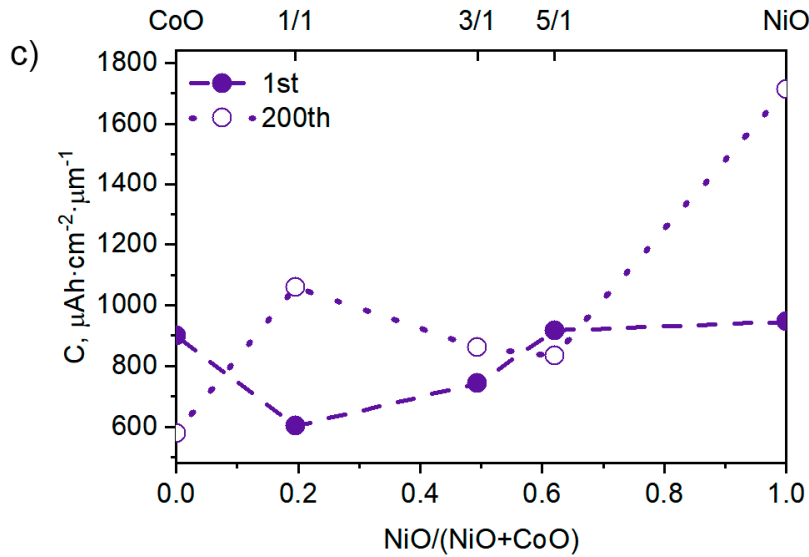

Figure 7. Components' contribution (a) before cycling, (b) after cycling, and (c) charge capacities of the films.

Figure 7c shows the specific discharge capacities for the first cycles and after the cycle life test (200 cycles). Although the SEI film's contribution increased, the overall capacity of $\mathrm{CoO}$ films decreased due to degradation of the TMO phase (Figure 7a,b). The NCO-3/1 and NCO-5/1 samples showed nearly equal capacity values before and after the cycle life tests. The growth of SEI film capacity compensated the loss of capacity due to transition metal degradation. The augmentation of $\mathrm{NCO}-1 / 1$ and $\mathrm{NiO}$ total capacity (by a factor of 1.5-1.8) was related to SEI film growth caused by increased surface area (Figure $4 \mathrm{~b}$ ) and high concentration of nickel atoms at the surface, respectively.

\section{Conclusions}

Thin films of nickel-cobalt oxide were successfully prepared by ALD using nickelocene and cobaltocene as metal-precursors, and remote oxygen plasma as a counter-reagent. Changing the ratio of metal-precursor pulses allowed precise changing and controlling of the film composition. The films obtained possessed a uniform chemical composition along the depth with an admixture of metallic nickel and carbon up to 4 at.\%. Comparing growth rate data of mono oxides (NO and $\mathrm{CO}$ ) with the rates of $\mathrm{NCO}$ oxides showed that the growth of the phase or phases of the binary metals oxide was increased.

XRD data showed that NCO samples contained a spinel $\mathrm{Ni}_{x} \mathrm{Co}_{(1-x)} \mathrm{O}_{2}$-phase with a cubic structure $\mathrm{Fm}-3 \mathrm{~m}$. With increased $\mathrm{Ni}$ content of the $\mathrm{Ni}_{\mathrm{x}} \mathrm{Co}_{1-\mathrm{x}} \mathrm{O}$ phase, the unit cell 
parameter decreased from 4.244 to $4.161 \AA$. XRR data show that all samples consisted of a layer uniform in density with a roughness of 0.63 to $3.23 \mathrm{~nm}$. With decreasing Ni content, the film density decreased from 6.60 to $6.31 \mathrm{~g} / \mathrm{cm}^{3}$.

The SEM study of the chips of the film deposited on steel substrates revealed an increase in the GPC up to 35\% compared to films deposited on the silicon substrates. On the surface of the NCO-1/1 samples with the smallest nickel content, nickel-oxide whisker nanocrystals were observed.

Electrochemical studies of all samples were carried out at charge current densities from $10 \mu \mathrm{A} / \mathrm{cm}^{2}$ (about $0.3 \mathrm{C}$ ) to $800 \mu \mathrm{A} / \mathrm{cm}^{2}$ (about $33 \mathrm{C}$ ). With an 80 -fold increase in the current density, the samples' discharge capacity decreased by only $21-33 \%$ (on average, from 920 to $655 \mu \mathrm{Ah} / \mathrm{cm}^{2} / \mu \mathrm{m}$ ). The moderate decrease in capacity was likely due to the small thickness of the films.

Supplementary Materials: The following are available online at https://www.mdpi.com/article/ 10.3390/nano11040907/s1, Figure S1: NiO XRR pattern, Figure S2: NCO-5/1 XRR pattern, Figure S3: NCO-3/1 XRR pattern, Figure S4: NCO-1/1 XRR pattern, Figure S5: CoO XRR pattern, Figure S6: Cyclic voltammetry curves of NCO-1/1 sample in 0.08-3.00 V range, Figure S7: SEM image of NCO-5/ 1 thin film at $200 \mathrm{kX}$ magnification, after CV (205 cycles), Figure S8: SEM image of NCO-5/1 thin film at $97.6 \mathrm{kX}$ magnification, above figure 1 area after $24 \mathrm{~s}$.

Author Contributions: Conceptualization, M.Y.M. and Y.K.; methodology, M.Y.M.; supervision, M.Y.M.; project administration, M.Y.M.; validation, M.Y.M., Y.K.; data curation, M.Y.M., formal analysis, I.M., D.N., I.E.; investigation, Y.K., I.M., I.E., A.K., D.N., A.R.; writing-review \& editing, M.Y.M., Y.K., I.M., I.E., D.N., A.K., A.R.; writing-original draft, D.N., O.M., Y.K.; visualization, I.M., O.M.; formal analysis, O.M., I.M., I.E., A.R.; resources, M.Y.M., A.P.; funding acquisition, M.Y.M. All authors have read and agreed to the published version of the manuscript.

Funding: The research was conducted under the financial support of the Russian Science Foundation grant (project No. 18-73-10015).

Data Availability Statement: Data available on request due to restrictions on privacy. The data presented in this study are available on request from the corresponding author.

Conflicts of Interest: The authors declare no conflict of interest. The funders had no role in the design of the study; in the collection, analyses, or interpretation of data; in the writing of the manuscript, or in the decision to publish the results.

\section{References}

1. Goldstein, M. IEEE Computer Society Phoenix Chapter Internet of Things Innovations \& Megatrends Update. Available online: https: / / www.slideshare.net/markgirc/ieee-computer-society-phoenix-chapter-internet-of-things-innovations-megatrendsupdate-121119 (accessed on 3 August 2020).

2. CeraCharge ${ }^{\mathrm{TM}}$. Backup Battery for Real Time Clock; TDK Electronics AG Piezo \& Protection Devices Business Group Multilayer Technology: Munich, Germany, 1 May 2020. Available online: https:/ /www.tdk-electronics.tdk.com/download/2831894/a593 2aa34a732bb2ad827025c862e61f/06-dl---real-time-clock.pdf (accessed on 17 June 2020).

3. Shirvanimoghaddam, M.; Shirvanimoghaddam, K.; Abolhasani, M.M.; Farhangi, M.; Barsari, V.Z.; Liu, H.Y.; Dohler, M.; Naebe, M. Towards a Green and Self-Powered Internet of Things Using Piezoelectric Energy Harvesting. IEEE Access 2019, 7, 94533-94556. [CrossRef]

4. Manthiram, A.; Knight, J.C.; Myung, S.T.; Oh, S.M.; Sun, Y.K. Nickel-Rich and Lithium-Rich Layered Oxide Cathodes: Progress and Perspectives. Adv. Energy Mater. 2016, 6. [CrossRef]

5. Sun, C.W.; Liu, J.; Gong, Y.D.; Wilkinson, D.P.; Zhang, J.J. Recent advances in all-solid-state rechargeable lithium batteries. Nano Energy 2017, 33, 363-386. [CrossRef]

6. Zhao, Y.; Li, X.F.; Yan, B.; Xiong, D.B.; Li, D.J.; Lawes, S.; Sun, X.L. Recent Developments and Understanding of Novel Mixed Transition-Metal Oxides as Anodes in Lithium Ion Batteries. Adv. Energy Mater. 2016, 6. [CrossRef]

7. Huang, Z.D.; Zhang, K.; Zhang, T.T.; Yang, X.S.; Liu, R.Q.; Li, Y.; Lin, X.J.; Feng, X.M.; Ma, Y.W.; Huang, W. Hierarchical NiCoO 2 mesoporous microspheres as anode for lithium ion batteries with superior rate capability. Energy Storage Mater. 2016, 3, 36-44. [CrossRef]

8. Bruce, P.G.; Scrosati, B.; Tarascon, J.M. Nanomaterials for rechargeable lithium batteries. Angew. Chem. Int. Ed. 2008, 47, 2930-2946. [CrossRef]

9. Wu, H.B.; Chen, J.S.; Hng, H.H.; Lou, X.W. Nanostructured metal oxide-based materials as advanced anodes for lithium-ion batteries. Nanoscale 2012, 4, 2526-2542. [CrossRef] 
10. Moitzheim, S.; Put, B.; Vereecken, P.M. Advances in 3D Thin-Film Li-Ion Batteries. Adv. Mater. Interfaces 2019, 6, 17. [CrossRef]

11. Oudenhoven, J.F.M.; Baggetto, L.; Notten, P.H.L. All-Solid-State Lithium-Ion Microbatteries: A Review of Various ThreeDimensional Concepts. Adv. Energy Mater. 2011, 1, 10-33. [CrossRef]

12. Pearse, A.; Schmitt, T.; Sahadeo, E.; Stewart, D.M.; Kozen, A.; Gerasopoulos, K.; Talin, A.A.; Lee, S.B.; Rubloff, G.W.; Gregorczyk, K.E. Three-Dimensional Solid-State Lithium-Ion Batteries Fabricated by Conformal Vapor-Phase Chemistry. ACS Nano 2018, 12, 4286-4294. [CrossRef] [PubMed]

13. Notten, P.H.L.; Roozeboom, F.; Niessen, R.A.H.; Baggetto, L. 3-D integrated all-solid-state rechargeable batteries. Adv. Mater. 2007, 19, 4564-4567. [CrossRef]

14. Baggetto, L.; Niessen, R.A.H.; Roozeboom, F.; Notten, P.H.L. High energy density all-solid-state batteries: A challenging concept towards 3D integration. Adv. Funct. Mater. 2008, 18, 1057-1066. [CrossRef]

15. Chernyaeva, O.Y.; Kyashkin, V.M.; Ivleva, A.Y.; Yrova, V.Y.; Solovyova, E.O. The influence of process conditions on the phase composition of the LiFePO4 film obtained by the atomic layer method. Polyhedron 2019, 157, 297-300. [CrossRef]

16. Liu, J.; Banis, M.N.; Sun, Q.; Lushington, A.; Li, R.Y.; Sham, T.K.; Sun, X.L. Rational Design of Atomic-Layer-Deposited LiFePO4 as a High-Performance Cathode for Lithium-Ion Batteries. Adv. Mater. 2014, 26, 6472-6477. [CrossRef]

17. Liu, J.; Xiao, B.W.; Banis, M.N.; Li, R.Y.; Sham, T.K.; Sun, X.L. Atomic layer deposition of amorphous iron phosphates on carbon nanotubes as cathode materials for lithium-ion batteries. Electrochim. Acta 2015, 162, 275-281. [CrossRef]

18. Donders, M.E.; Arnoldbik, W.M.; Knoops, H.C.M.; Kessels, W.M.M.; Notten, P.H.L. Atomic Layer Deposition of LiCoO2 Thin-Film Electrodes for All-Solid-State Li-Ion Micro-Batteries. J. Electrochem. Soc. 2013, 160, A3066-A3071. [CrossRef]

19. Donders, M.E.; Knoops, H.C.M.; Kessels, W.M.M.; Notten, P.H.L. Remote Plasma Atomic Layer Deposition of Thin Films of Electrochemically Active $\mathrm{LiCoO}_{2}$. In Atomic Layer Deposition Applications 7; Elam, J.W., Londergan, A., VanDerStraten, O., Roozeboom, F., DeGendt, S., Bent, S.F., Delabie, A., Eds.; ECS Transactions: San Francisco, CA, USA, 2011; Volume 41, pp. 321-330.

20. Miikkulainen, V.; Ruud, A.; Ostreng, E.; Nilsen, O.; Laitinen, M.; Sajavaara, T.; Fjellvag, H. Atomic Layer Deposition of Spinel Lithium Manganese Oxide by Film-Body-Controlled Lithium Incorporation for Thin-Film Lithium-Ion Batteries. J. Phys. Chem. C 2014, 118, 1258-1268. [CrossRef]

21. Nieminen, H.E.; Miikkulainen, V.; Settipani, D.; Simonelli, L.; Honicke, P.; Zech, C.; Kayser, Y.; Beckhoff, B.; Honkanen, A.P.; Heikkila, M.J.; et al. Intercalation of Lithium Ions from Gaseous Precursors into beta-MnO2 Thin Films Deposited by Atomic Layer Deposition. J. Phys. Chem. C 2019, 123, 15802-15814. [CrossRef]

22. Young, M.J.; Schnabel, H.D.; Holder, A.M.; George, S.M.; Musgrave, C.B. Band Diagram and Rate Analysis of Thin Film Spinel $\mathrm{LiMn}_{2} \mathrm{O}_{4}$ Formed by Electrochemical Conversion of ALD-Grown MnO. Adv. Funct. Mater. 2016, 26, 7895-7907. [CrossRef]

23. Baddour-Hadjean, R.; Golabkan, V.; Pereira-Ramos, J.P.; Mantoux, A.; Lincot, D. A Raman study of the lithium insertion process in vanadium pentoxide thin films deposited by atomic layer deposition. J. Raman Spectrosc. 2002, 33, 631-638. [CrossRef]

24. Badot, J.C.; Mantoux, A.; Baffier, N.; Dubrunfaut, O.; Lincot, D. Electrical properties of $\mathrm{V}_{2} \mathrm{O}_{5}$ thin films obtained by atomic layer deposition (ALD). J. Mater. Chem. 2004, 14, 3411-3415. [CrossRef]

25. Badot, J.C.; Mantoux, A.; Baffier, N.; Dubrunfaut, O.; Lincot, D. Submicro- and nanostructural eff ects on electrical properties of $\mathrm{Li}_{0.2} \mathrm{~V}_{2} \mathrm{O}_{5}$ thin films obtained by atomic layer deposition (ALD). J. Phys. Chem. Solids 2006, 67, 1270-1274. [CrossRef]

26. Prasadam, V.P.; Bahlawane, N.; Mattelaer, F.; Rampelberg, G.; Detavernier, C.; Fang, L.; Jiang, Y.; Martens, K.; Parkin, I.P.; Papakonstantinou, I. Atomic layer deposition of vanadium oxides: Process and application review. Mater. Today Chem. 2019, 12, 396-423. [CrossRef]

27. Wang, B.Q.; Liu, J.; Sun, Q.; Xiao, B.W.; Li, R.Y.; Sham, T.K.; Sun, X.L. Titanium Dioxide/Lithium Phosphate Nanocomposite Derived from Atomic Layer Deposition as a High-Performance Anode for Lithium Ion Batteries. Adv. Mater. Interfaces 2016, 3, 8. [CrossRef]

28. Kia, A.M.; Bonhardt, S.; Zybell, S.; Kuhnel, K.; Haufe, N.; Weinreich, W. Development of Rutile Titanium Oxide Thin Films as Battery Material Component Using Atomic Layer Deposition. Phys. Status Solidi 2020, 217, 1800769. [CrossRef]

29. Nazarov, D.V.; Maximov, M.Y.; Novikov, P.A.; Popovich, A.A.; Silin, A.O.; Smirnov, V.M.; Bobrysheva, N.P.; Osmolovskaya, O.M.; Osmolovsky, M.G.; Rumyantsev, A.M. Atomic layer deposition of tin oxide using tetraethyltin to produce high-capacity Li-ion batteries. J. Vac. Sci. Technol. A 2017, 35. [CrossRef]

30. Maximov, M.Y.; Novikov, P.A.; Nazarov, D.V.; Rymyantsev, A.M.; Silin, A.O.; Zhang, Y.; Popovich, A.A. Characterization and Electrochemical Performance at High Discharge Rates of Tin Dioxide Thin Films Synthesized by Atomic Layer Deposition. J. Electron. Mater. 2017, 46, 6571-6577. [CrossRef]

31. Zhao, B.; Mattelaer, F.; Kint, J.; Werbrouck, A.; Henderick, L.; Minjauw, M.; Dendooven, J.; Detavernier, C. Atomic layer deposition of $\mathrm{ZnO}-\mathrm{SnO}_{2}$ composite thin film: The influence of structure, composition and crystallinity on lithium-ion battery performance. Electrochim. Acta 2019, 320, 13. [CrossRef]

32. Kint, J.; Mattelaer, F.; Minjauw, M.; Zhao, B.; Detavernier, C. Atomic layer deposition of thin films as model electrodes: A case study of the synergistic effect in $\mathrm{Fe}_{2} \mathrm{O}_{3}-\mathrm{SnO}_{2}$. J. Vac. Sci. Technol. A 2019, 37. [CrossRef]

33. Bonhardt, S.; Kuhnel, K.; Kia, A.M.; Weinreich, W. Formation of highly conformal spinel lithium titanate thin films based on a novel three-step atomic layer deposition process. J. Vac. Sci. Technol. A 2019, 37, 6. [CrossRef]

34. Meng, X.B.; Liu, J.; Li, X.F.; Banis, M.N.; Yang, J.L.; Li, R.Y.; Sun, X.L. Atomic layer deposited $\mathrm{Li}_{4} \mathrm{Ti}_{5} \mathrm{O}_{12}$ on nitrogen-doped carbon nanotubes. RSC Adv. 2013, 3, 7285-7288. [CrossRef] 
35. Miikkulainen, V.; Nilsen, O.; Laitinen, M.; Sajavaara, T.; Fjellvag, H. Atomic layer deposition of LixTiyOz thin films. RSC Adv. 2013, 3, 7537-7542. [CrossRef]

36. Kozen, A.C.; Pearse, A.J.; Lin, C.F.; Noked, M.; Rubloff, G.W. Atomic Layer Deposition of the Solid Electrolyte LiPON. Chem. Mater. 2015, 27, 5324-5331. [CrossRef]

37. Put, B.; Mees, M.J.; Hornsveld, N.; Hollevoet, S.; Sepulveda, A.; Vereecken, P.M.; Kessels, W.M.M.; Creatore, M. Plasma-Assisted ALD of LiPO(N) for Solid State Batteries. J. Electrochem. Soc. 2019, 166, A1239-A1242. [CrossRef]

38. Wang, B.Q.; Zhao, Y.; Banis, M.N.; Sun, Q.; Adair, K.R.; Li, R.Y.; Sham, T.K.; Sun, X.L. Atomic Layer Deposition of Lithium Niobium Oxides as Potential Solid-State Electrolytes for Lithium-Ion Batteries. ACS Appl. Mater. Interfaces 2018, 10, 1654-1661. [CrossRef]

39. Ostreng, E.; Sonsteby, H.H.; Sajavaara, T.; Nilsen, O.; Fjellvag, H. Atomic layer deposition of ferroelectric LiNbO 3 . J. Mater. Chem. C 2013, 1, 4283-4290. [CrossRef]

40. Atosuo, E.; Mantymaki, M.; Mizohata, K.; Heikkila, M.J.; Raisanen, J.; Ritala, M.; Leskela, M. Preparation of Lithium Containing Oxides by the Solid State Reaction of Atomic Layer Deposited Thin Films. Chem. Mater. 2017, 29, 998-1005. [CrossRef]

41. Amirmaleki, M.; Cao, C.H.; Wang, B.Q.; Zhao, Y.; Cui, T.; Tam, J.; Sun, X.L.; Sun, Y.; Filleter, T. Nanomechanical elasticity and fracture studies of lithium phosphate (LPO) and lithium tantalate (LTO) solid-state electrolytes. Nanoscale 2019, 11, 18730-18738. [CrossRef]

42. Liu, J.; Banis, M.N.; Li, X.F.; Lushington, A.; Cai, M.; Li, R.Y.; Sham, T.K.; Sun, X.L. Atomic Layer Deposition of Lithium Tantalate Solid-State Electrolytes. J. Phys. Chem. C 2013, 117, 20260-20267. [CrossRef]

43. Li, X.F.; Liu, J.; Banis, M.N.; Lushington, A.; Li, R.Y.; Cai, M.; Sun, X.L. Atomic layer deposition of solid-state electrolyte coated cathode materials with superior high-voltage cycling behavior for lithium ion battery application. Energy Environ. Sci. 2014, 7, 768-778. [CrossRef]

44. Comstock, D.J.; Elam, J.W. Mechanistic Study of Lithium Aluminum Oxide Atomic Layer Deposition. J. Phys. Chem. C 2013, 117, 1677-1683. [CrossRef]

45. Miikkulainen, V.; Nilsen, O.; Li, H.; King, S.W.; Laitinen, M.; Sajavaara, T.; Fjellvag, H. Atomic layer deposited lithium aluminum oxide: (In)dependency of film properties from pulsing sequence. J. Vac. Sci. Technol. A 2015, 33, 7. [CrossRef]

46. Aaltonen, T.; Alnes, M.; Nilsen, O.; Costelle, L.; Fjellvag, H. Lanthanum titanate and lithium lanthanum titanate thin films grown by atomic layer deposition. J. Mater. Chem. 2010, 20, 2877-2881. [CrossRef]

47. Wang, B.Q.; Liu, J.; Banis, M.N.; Sun, Q.; Zhao, Y.; Li, R.Y.; Sham, T.K.; Sun, X.L. Atomic Layer Deposited Lithium Silicates as Solid-State Electrolytes for All-Solid-State Batteries. ACS Appl. Mater. Interfaces 2017, 9, 31786-31793. [CrossRef]

48. Aaltonen, T.; Nilsen, O.; Magraso, A.; Fjellvag, H. Atomic Layer Deposition of $\mathrm{Li}_{2} \mathrm{O}-\mathrm{Al}_{2} \mathrm{O}_{3}$ Thin Films. Chem. Mater. 2011, 23, 4669-4675. [CrossRef]

49. Kazyak, E.; Chen, K.H.; Davis, A.L.; Yu, S.; Sanchez, A.J.; Lasso, J.; Bielinski, A.R.; Thompson, T.; Sakamoto, J.; Siegel, D.J.; et al. Atomic layer deposition and first principles modeling of glassy $\mathrm{Li}_{3} \mathrm{BO}_{3}-\mathrm{Li}_{2} \mathrm{CO}_{3}$ electrolytes for solid-state $\mathrm{Li}$ metal batteries. $J$. Mater. Chem. A 2018, 6, 19425-19437. [CrossRef]

50. Kazyak, E.; Chen, K.H.; Wood, K.N.; Davis, A.L.; Thompson, T.; Bielinski, A.R.; Sanchez, A.J.; Wang, X.; Wane, C.M.; Sakamoto, J.; et al. Atomic Layer Deposition of the Solid Electrolyte Garnet $\mathrm{Li}_{7} \mathrm{La}_{3} \mathrm{Zr}_{2} \mathrm{O}_{12}$. Chem. Mater. 2017, 29, 3785-3792. [CrossRef]

51. Hofstetter, K.; Samson, A.J.; Dai, J.Q.; Gritton, J.E.; Hu, L.B.; Wachsman, E.D.; Thangadurai, V. Electrochemical Stability of Garnet-Type $\mathrm{Li}_{7} \mathrm{La}_{2.75} \mathrm{Ca}_{0.25} \mathrm{Zr}_{1.75} \mathrm{Nb}_{0.25} \mathrm{O}_{12}$ with and without Atomic Layer Deposited-Al2 $\mathrm{O}_{3}$ under $\mathrm{CO}_{2}$ and $\mathrm{Humidity}_{\text {. J. }}$ Electrochem. Soc. 2019, 166, A1844-A1852. [CrossRef]

52. Nisula, M.; Shindo, Y.; Koga, H.; Karppinen, M. Atomic Layer Deposition of Lithium Phosphorus Oxynitride. Chem. Mater. 2015, 27, 6987-6993. [CrossRef]

53. Shibata, S. Thermal Atomic Layer Deposition of Lithium Phosphorus Oxynitride as a Thin-Film Solid Electrolyte. J. Electrochem. Soc. 2016, 163, A2555-A2562. [CrossRef]

54. Hagen, D.J.; Tripathi, T.S.; Karppinen, M. Atomic layer deposition of nickel-cobalt spinel thin films. Dalton Trans. 2017, 46, 4796-4805. [CrossRef]

55. Koshtyal, Y.; Nazarov, D.; Ezhov, I.; Mitrofanov, I.; Kim, A.; Rymyantsev, A.; Lyutakov, O.; Popovich, A.; Maximov, M. Atomic Layer Deposition of NiO to Produce Active Material for Thin-Film Lithium-Ion Batteries. Coatings 2019, 9, 301. [CrossRef]

56. Maximov, M.; Nazarov, D.; Rumyantsev, A.; Koshtyal, Y.; Ezhov, I.; Mitrofanov, I.; Kim, A.; Medvedev, O.; Popovich, A. Atomic Layer Deposition of Lithium-Nickel-Silicon Oxide Cathode Material for Thin-Film Lithium-Ion Batteries. Energies 2020, 13, 2345. [CrossRef]

57. Mitrofanov, I.; Ezhov, I.; Yury, K.; Nazarov, D.; Kim, A.; Rumyantsev, A.; Popovich, A.; Maximov, M. Synthesis of lithium and cobalt oxides systems by the ALD method to obtain lithium cobalt oxide cathode for thin-film LIBs. In Proceedings of the Nanocon 2019 11th International Conference on Nanomaterials Research \& Application, Brno, Czech Republic, 16-18 October 2019; pp. 251-256.

58. Mackus, A.J.M.; Schneider, J.R.; MacIsaac, C.; Baker, J.G.; Bent, S.F. Synthesis of Doped, Ternary, and Quaternary Materials by Atomic Layer Deposition: A Review. Chem. Mater. 2019, 31, 1142-1183. [CrossRef]

59. Wang, Y.P.; Ding, Z.J.; Zhu, B.; Liu, W.J.; Zhang, D.W.; Ding, S.J. Atomic layer deposition of amorphous Ni-Ta-N films for Cu diffusion barrier. J. Vac. Sci. Technol. A 2018, 36. [CrossRef]

60. Qian, S.B.; Wang, Y.P.; Shao, Y.; Liu, W.J.; Ding, S.J. Plasma-Assisted Atomic Layer Deposition of High-Density Ni Nanoparticles for Amorphous In-Ga-Zn-O Thin Film Transistor Memory. Nanoscale Res. Lett. 2017, 12, 138. [CrossRef] 
61. Marrani, A.G.; Novelli, V.; Sheehan, S.; Dowling, D.P.; Dini, D. Probing the Redox States at the Surface of Electroactive Nanoporous NiO Thin Films. ACS Appl. Mater. Interfaces 2014, 6, 143-152. [CrossRef] [PubMed]

62. Kang, J.-K.; Rhee, S.-W. Chemical vapor deposition of nickel oxide films from $\mathrm{Ni}_{(}\left(\mathrm{C}_{5} \mathrm{H}_{5}\right)_{2} / \mathrm{O}_{2}$. Thin Solid Films 2001, 391, 57-61. [CrossRef]

63. Moulder, J.F.; Stickle, W.F.; Sobol, P.E.; Bomben, K.D. Handbook of X-ray Photoelectron Spectroscopy: A Reference Book of Standard Spectra for Identification and Interpretation of XPS Data; Chaistain, J., Ed.; Perkin-Elmer Corporation, Physical Electronics Devision: Eden Prairie Minnesota, MN, USA, 1995.

64. Biesinger, M.C.; Payne, B.P.; Grosvenor, A.P.; Lau, L.W.M.; Gerson, A.R.; Smart, R.S. Resolving surface chemical states in XPS analysis of first row transition metals, oxides and hydroxides: Cr, Mn, Fe, Co and Ni. Appl. Surf. Sci. 2011, 257, 2717-2730. [CrossRef]

65. Adhikari, H.; Marshall, A.F.; Goldthorpe, I.A.; Chidsey, C.E.D.; McIntyre, P.C. Metastability of Au-Ge liquid nanocatalysts: Ge vapor-liquid-solid nanowire growth far below the bulk eutectic temperature. ACS Nano 2007, 1, 415-422. [CrossRef]

66. Wang, T.; Jiang, T.; Meng, X. Gallium-assisted growth of InSb nanowire. Rev. Mex. Fis. 2019, 65, 601-606. [CrossRef]

67. Dao, K.A.; Dao, D.K.; Nguyen, T.D.; Phan, A.T.; Do, H.M. The effects of Au surface diffusion to formation of Au droplets/clusters and nanowire growth on GaAs substrate using VLS method. J. Mater. Sci. Mater. Electron. 2012, 23, 2065-2074. [CrossRef]

68. Yu, H.K.; Lee, J.L. Growth mechanism of metal-oxide nanowires synthesized by electron beam evaporation: A self-catalytic vapor-liquid-solid process. Sci. Rep. 2014, 4, 6589. [CrossRef] [PubMed]

69. Luo, L.L.; Zou, L.F.; Schreiber, D.K.; Baer, D.R.; Bruemmer, S.M.; Zhou, G.W.; Wang, C.M. In-situ transmission electron microscopy study of surface oxidation for Ni-10Cr and Ni-20Cr alloys. Scr. Mater. 2016, 114, 129-132. [CrossRef]

70. Cao, F.; Jia, S.F.; Zheng, H.; Zhao, L.L.; Liu, H.H.; Li, L.; Zhao, L.G.; Hu, Y.M.; Gu, H.S.; Wang, J.B. Thermal-induced formation of domain structures in $\mathrm{CuO}$ nanomaterials. Phys. Rev. Mater. 2017, 1, 053401. [CrossRef]

71. Xu, X.; Dong, B.T.; Ding, S.J.; Xiao, C.H.; Yu, D.M. Hierarchical $\mathrm{NiCoO}_{2}$ nanosheets supported on amorphous carbon nanotubes for high-capacity Lithium-ion batteries with a long cycle life. J. Mater. Chem. A 2014, 2, 13069-13074. [CrossRef]

72. Wei, Y.H.; Yan, F.L.; Tang, X.; Luo, Y.Z.; Zhang, M.; Wei, W.F.; Chen, L.B. Solvent-Controlled Synthesis of NiO-CoO/Carbon Fiber Nanobrushes with Different Densities and Their Excellent Properties for Lithium Ion Storage. ACS Appl. Mater. Interfaces 2015, 7, 21703-21711. [CrossRef]

73. Liu, Y.G.; Zhao, Y.Y.; Yu, Y.L.; Ahmad, M.; Sun, H.Y. Facile synthesis of single-crystal mesoporous $\mathrm{CoNiO}_{2}$ nanosheets assembled flowers as anode materials for lithium-ion batteries. Electrochim. Acta 2014, 132, 404-409. [CrossRef]

74. Cao, K.Z.; Jin, T.; Yang, L.; Jiao, L.F. Recent progress in conversion reaction metal oxide anodes for Li-ion batteries. Mater. Chem. Front. 2017, 1, 2213-2242. [CrossRef] 